\title{
TOWARD ELIMINATING BARGAIN BASEMENT JUSTICE: PROVIDING INDIGENT DEFENDANTS WITH EXPERT SERVICES AND AN ADEQUATE DEFENSE
}

\author{
FRED WARREN BENNETT
}

\begin{abstract}
There can be no equal justice where the kind of trial a man gets depends on the amount of money he has. ${ }^{1}$
\end{abstract}

The methods we employ in the enforcement of our criminal law have aptly been called the measures by which the quality of our civilization may be judged. ${ }^{2}$

\section{INTRODUCTION}

Almost four decades ago, in Griffin v. Illinois, ${ }^{3}$ Justice Hugo Black noted the ancient problem of providing equal justice for the rich and for the poor. ${ }^{4}$ After citing the Bible ${ }^{5}$ and the Magna Charta,${ }^{6}$ Justice Black noted that "[ $[\mathrm{b}]$ oth equal protection and due process emphasize the central aim of our entire judicial system-all people 'stand on an equality before the bar of justice in every American court'."7 In a five-to-four decision, the Supreme Court held that the state had both an equal protection and a due process obligation to provide free trial transcripts to indigent defendants appealing their convictions. ${ }^{8}$

Copyright 101995 by Law and Contemporary Problems

* Associate Professor of Law, Columbus School of Law, the Catholic University of America.

I wish to gratefully acknowledge and thank Scott Brooksby, a 1994 graduate of the Columbus School of Law, the Catholic University of America, for his research and assistance on this article.

1. Griffin v. Illinois, 351 U.S. 12, 19 (1956).

2. Coppedge v. United States, 369 U.S. 438, 449 (1962).

3. 351 U.S. 12 (1956).

4. Id. at 17. Justice Black, noting Hovey v. Elliott, 167 U.S. 409 (1897), stated rhetorically that defendants who are unable to pay court costs in advance should not be denied the right to plead not guilty or to defend themselves in court. Griffin, 351 U.S. at 17.

5. Griffin, 351 U.S. at 16 (citing Leviticus 19:15: "Ye shall do no unrighteousness in judgment; thou shall not respect the person of the poor, nor honour the person of the mighty: but in righteousness shalt thou judge thy neighbor.").

6. Id. The Magna Charta, executed in 1215, provided:

To no one will we sell, to no one will we refuse, or delay, right or justice .... No free man shall be taken or imprisoned, or disseised, or outlawed, or exiled, or anywise destroyed; nor shall we go upon him nor send upon him, but by the lawful judgment of his peers or by the law of the land.

7. Id. at 17 (citing Chambers v. Florida, 309 U.S. 227, 241 (1940)).

8. Id. at 18-19. 
In Griffin, the Supreme Court began to provide greater procedural protections, in the form of expert services, for indigent defendants at the state level. Prior to Griffin, some, but not all, states denied indigents a free transcript for appeal; ${ }^{9}$ procedural protections had been limited largely to the provision of counsel, and even then only in specified circumstances. ${ }^{10}$ Gradually, the right of an indigent defendant to appointed counsel became clear and systematized. ${ }^{11}$ During the 1950s and 1960s, the Supreme Court and federal appellate courts began to focus on providing for the poor the "meaningful access to justice"12 and the "basic tools of an adequate defense"13 which indigents so desperately need ${ }^{14}$ including the right to court-appointed counsel at the state level ${ }^{15}$ and expert services.

Although the Supreme Court began as early as 1932 in Powell v. Alabama ${ }^{16}$ to define the boundaries of an indigent's right to appointed counsel, the Court decided very few cases in the area of providing experts and expert services for the indigent. In the only Supreme Court case before Ake v. Oklahoma ${ }^{17}$ on the matter of state-funded psychiatric assistance for an indigent defendant, United States ex rel. Smith $v$. Baldi, ${ }^{18}$ the Court held that the denial of a motion by an indigent defendant for a pretrial psychiatric consultation did not constitute a denial of due process. ${ }^{19}$ Prior to $A k e$, some state courts erroneously cited Baldi to justify a complete denial of psychiatric defense assistance to indigents who requested but could not otherwise afford such assistance. ${ }^{20}$ The better

9. Id at 19.

10. See, e.g., Powell v. Alabama, 287 U.S. 45 (1932) (holding that in capital cases the 14th Amendment requires intensified protection for the indigent and that failure to provide counsel for a rape defendant was a denial of fundamental fairness).

11. Powell did not entitle all indigent defendants to counsel. In Johnson v. Zerbst, 304 U.S. 458 (1938), the right of an indigent to appointed counsel was established under the Sixth Amendment. In Betts v. Brady, 316 U.S. 455 (1942), the Court held that the sixth amendment requirement that indigent defendants receive appointed counsel in certain federal criminal proceedings did not apply to the states because it was not a fundamental right essential to a fair trial. Id. at 471-73.

12. Ake v. Oklahoma, 470 U.S. 68,77 (1985) (holding that defendant has a right to a state-funded psychiatrist if insanity is a significant factor at the trial).

13. Britt v. North Carolina, 404 U.S. 226, 227 (1971).

14. See United States v. Johnson, 238 F.2d 565, 572 (2d Cir. 1956) (Frank, J., dissenting) ("The best lawyer in the world cannot competently defend an accused person if the lawyer cannot obtain existing evidence crucial to the defense .... In such circumstances, if the government does not supply the funds, justice is denied the poor-and represents but an upper-bracket privilege."), vacated, 352 U.S. 565 (1957).

15. In Gideon v. Wainwright, 372 U.S. 335 (1963), the right to counsel at trial became a "fundamental right," meaning states must provide counsel for indigent defendants. The Court noted that the "right of one charged with crime to counsel may not be deemed fundamental and essential to fair trials in some countries, but it is in ours." Id. at 344 .

16. 287 U.S. 45 (1932).

17. 470 U.S. 68 (1985).

18. 344 U.S. 561 (1953). In Baldi, the defendant pled guilty to first-degree murder and then presented testimony on an insanity defense at a later hearing. Id. at 564.

19. Id. at 568.

20. See, for example, Irvin v. State, 617 P.2d 588 (Okla. Crim. App. 1980), superseded by statute as stated in Dutten v. Dixon, 757 P.2d 376 (Okla. Crim. App. 1988), overruled in part by Cartwright v. State, 778 P.2d 479 (Okla. Crim. App. 1989), cert. denied, 497 U.S. 1015 (1990), and Taylor v. State, 192 S.E.2d 249 (Ga. 1972), which relied on Baldi to find no error in a trial court's refusal to appoint a 
interpretation of Baldi holds that because the defendant had been provided with sufficient psychiatric defense assistance, he was not constitutionally entitled to further assistance at state expense. ${ }^{21}$

The right of an indigent defendant to expert services may well have been presaged by Griffin. The development of Griffin and its progeny, ${ }^{22}$ as well as the growth of the right of an indigent to counsel provided by Gideon $v$. Wainright ${ }^{23}$ and Douglas $v$. California, ${ }^{24}$ eventually would be extended to provide an indigent with a right to experts and expert services. The landmark decision providing indigent defendants access to psychiatric expert services, and arguably other types of expert services, came in 1985 with Ake v. Oklahoma. ${ }^{25}$ In $A k e$, the Court held that if a defendant's sanity at the time of the offense is to be a "significant factor" at the trial of an indigent defendant, the indigent has a right to the assistance of a state-supplied psychiatrist to aid in the defense. ${ }^{26}$

Despite the Supreme Court decisions in Griffin and Ake, and statutory provisions providing expert services for an indigent, ${ }^{27}$ it remains unclear whether an indigent will be provided with the expert services necessary for an adequate defense. ${ }^{28}$ This article examines the line of cases that provide expert

psychiatrist requested by the indigent defendant. See also Martin v. Commonwealth, 271 S.E.2d 123 (Va. 1980), in which the Supreme Court of Virginia, citing Baldi as its authority, upheld the trial court's denial of a state-paid investigator for an indigent defendant.

21. See Bush v. McCollum, 231 F. Supp. 560 (N.D. Tex. 1964), aff'd, 344 F.2d 672 (5th Cir. 1965). In Bush, the court held that an indigent defendant planning a defense of insanity at a contested trial (Baldi, by contrast, pled guilty and complained later of ineffective assistance of counsel) was denied due process under the 14th Amendment when his request to the trial court for a psychiatrist to assist his defense was denied. Id. at 565 .

22. Subsequent cases further delineated the bounds of the indigent defendant's or prisoner's right to a free transcript as an expert service. See, e.g., Mayer v. Chicago, 404 U.S. 189, 193 (1971) (holding that an indigent defendant has an equal protection right to a free transcript for appeal); Draper v. Washington, 372 U.S. 487, 488 (1963) (holding that access to a free transcript for purposes of appeal cannot be denied to indigent defendants).

23. 372 U.S. 335 (1963) (holding that the right of an indigent defendant in a criminal trial to have the assistance of counsel is a fundamental right essential to a fair trial that must be observed by the states under the 14th Amendment).

24. 372 U.S. 353 (1963) (holding that under the 14th Amendment a defendant is entitled as of right to a court-appointed attorney on an appeal). Douglas was decided on the same day as Gideon. The Douglas decision was based on the equal protection language that runs throughout Griffin v. Illinois, 351 U.S. 12 (1956).

25. 470 U.S. 68 (1985). For a fuller discussion of Ake, see infra notes $75-91$ and accompanying text.

26. 470 U.S. at 74. The Court stated:

We hold that when a defendant has made a preliminary showing that his sanity at the time of the offense is likely to be a significant factor at trial, the Constitution requires that a State provide access to a psychiatrist's assistance on this issue if the defendant cannot otherwise Id. afford one.

27. The statutory focus of this article will be on the Criminal Justice Act of 1964, 18 U.S.C. $\S 3006 \mathrm{~A}(\mathrm{e})(1988)$, which provides for expert services in federal courts for those defendants who cannot afford them. Various state statutes will also be considered. See infra part V.B.

28. For discussions of the pre-Ake treatment of expert services by the courts, see Ephraim Margolin \& Allen Wagner, The Indigent Criminal Defendant and Defense Services: A Search for Constitutional Standards, 24 HASTINGS L.J. 647 (1973); Dennis W. Alexander, Comment, Assistance in Addition to Counsel for Indigent Defendants; The Need For; The Lack Of; The Right To, 16 VILL. L. REV. 323 (1970); Philip Fahringer, Note, An Indigent Criminal Defendant's Constitutional Right to a Psychiatric 
services for the indigent and have as a consistent theme the "meaningful access to justice."29 Particular emphasis will be given to the need for nonpsychiatric experts, in an effort to show that nonpsychiatric experts are a basic "tool of an adequate defense" 30 that should be provided for those who cannot afford to retain such experts. ${ }^{31}$

Part II of this article discusses the historical background and the importance of providing an "adequate defense."32 Part III addresses substantive and procedural concerns and examines the standard for appointment of psychiatric and nonpsychiatric experts. Part IV considers the changing role of the expert and the importance of the expert as a member of the defense team. Part V discusses federal and state legislation providing expert services for the indigent and considers the problem of imposing statutory limitations on the compensation available to the expert appointed under federal or state legislation. Part VI discusses how courts should interpret $A k e$ to effectuate its meaning and concludes with a proposal of suggested statutory language for the authorization of defense services.

\section{II}

\section{THE HistoricAl BACKGROUND OF THE RIGHT TO EXPERT SERVICES FOR} THE POOR

\section{A. The Critical Importance of an "Adequate Defense"}

Since as early as Griffin in 1956, the Supreme Court has focused on identifying and providing for the indigent defendant the "tools of an adequate defense." If If as the Court has declared, fundamental fairness entitles indigent defendants to "an adequate opportunity to present their claims fairly within the adversary system,"34 then, as a corollary, the idea that indigent defendants must be provided with the same essential services (such as experts) available to the nonindigent becomes axiomatic. ${ }^{35}$

The Supreme Court has made it clear, however, that indigent defendants are not entitled to state or federal resources to duplicate the defense services

Expert, 1984 U. Ill. L. REV. 481; Dean C. Gramlich, Note, Equal Protection and the Indigent Defendant: Griffin and its Progeny, 16 STAN. L. REV. 394 (1964).

29. Ake, 470 U.S. at 77.

30. Id. (citing Britt v. North Carolina, 404 U.S. 226, 227 (1971)).

31. Id.

32. See 18 U.S.C. $\$ 3006$ A(e) (1988) (codifying the right to an adequate defense).

33. Britt v. North Carolina, 404 U.S. 226, 227 (1971). In Britt, while affirming the defendant's conviction because of a lack of showing of a need for a trial transcript, the Court held, consistent with Griffin, that an indigent defendant must be provided with the basic tools of an adequate defense or appeal when other prisoners or defendants may be able to purchase such tools. Id.; see also Ake, 470 U.S. 68.

34. Ross v. Moffitt, 417 U.S. 600,612 (1974).

35. Writing for the majority in Griffin v. Illinois, 351 U.S. 12 (1956), Justice Black wrote: "There can be no equal justice where the kind of trial a man gets depends on the amount of money he has." Id. at 19. Justice Black must have foreseen how difficult it would be to solve this rhetorical problem. 
(expert or otherwise) that a wealthier person can buy. ${ }^{36}$ Most lower federal courts have enthusiastically rejected the equal protection and due process arguments brought by indigent defendants seeking the services that paying clients can buy for themselves. In Williams $v$. Collins, ${ }^{37}$ for example, the defendant was convicted of capital murder. The court rejected the defendant's claim that the denial of an investigator constituted a deprivation of equal protection and due process. The court dismissively noted it is "well settled" that a state is not required "to pay for the same assistance that a wealthier defendant might buy."38 Comparatively few courts have found differences based on financial status "repugnant to the Constitution" when the vindication of legal rights is at issue. 39

Lower federal courts often adhere to Justice Frankfurter's concurring opinion in Griffin. ${ }^{40}$ Griffin's baseline holding, to which the plurality and concurrence subscribed, generally requires that once a state makes an appeal available to criminal defendants, it must provide them with a free transcript if they cannot afford one. ${ }^{41}$

Other decisions have expanded an indigent's right to an adequate defense. For example, indigent defendants need not pay a fee before they file a notice of appeal from their conviction. ${ }^{42}$ Of particular importance to an adequate defense are the rights to assistance of counsel at trial ${ }^{43}$ and the assistance of counsel on the first direct appeal. ${ }^{44}$ Clearly the mere appointment of counsel is not sufficient. It is also essential that once counsel is appointed for an indigent defendant, the assistance rendered is effective. ${ }^{45}$ In addition, fundamental to the necessary expansion of the components of an adequate defense are experts and expert services, both psychiatric and nonpsychiatric. ${ }^{46}$ One commentator argues that because criminal defendants are entitled to the effective assistance of counsel, the defendants are therefore entitled to the kinds

36. Ross, 417 U.S. at 612 . See also Justice Frankfurter's concurring opinion in Griffin, where he noted that the Equal Protection Clause does not require absolute matching by the government of the resources of defendants with means.

37. 16 F.3d 626 (5th Cir. 1994).

38. Id. at 637 (relying on $A k e, 470$ U.S. 68). The Texas Code of Criminal Procedure placed a $\$ 500$ limit on reimbursement of costs for court-appointed investigators. Curiously, although getting to the merits of the case, the Court of Appeals noted that the investigator in this particular case cost $\$ 900$ and that it was the policy of the sitting judges in habeas cases to reimburse in full; so, in fact, there was no harm to the defendant.

39. See, e.g., United States v. Devlin, 13 F.3d 1361, 1363 (9th Cir. 1994) (citing Roberts v. LaVallee, 389 U.S. 40,42 (1967)).

40. See Moore v. Kemp, 809 F.2d 702 (11th Cir.), cert. denied, 481 U.S. 1054 (1987).

41. Griffin v. Illinois, 351 U.S. 12,19 (1956).

42. Burns v. Ohio, 360 U.S. 252 (1959).

43. Gideon v. Wainwright, 372 U.S. 335,344 (1963).

44. Douglas v. California, 372 U.S. 353, 357 (1963).

45. See, e.g., Evitts v. Lucey, 469 U.S. 387, 395 (1985); Strickland v. Washington, 466 U.S. 668,685 (1984); McMann v. Richardson, 397 U.S. 759, 771 n.14 (1970).

46. See John M. West, Note, Expert Services and the Indigent Criminal Defendant: The Constitutional Mandate of Ake v. Oklahoma, 84 MICH. L. REV. 1326 (1986) (arguing that even when an indigent defendant is provided with counsel, justice is not always done). 
of services the defense attorneys would tend to employ were their clients not indigent. ${ }^{47}$

Through cases such as Griffin and Gideon, the Supreme Court considerably broadened the constitutional mandate of an adequate defense. The Griffin decision, providing transcripts to indigent criminal defendants for first appeals as of right, is an early precursor to the Court's formal pronouncement in Ake regarding the necessity of psychiatric experts in the presentation of an adequate defense. ${ }^{48}$

$A k e$, although sometimes problematic and inadequate, was and is an opinion that grounds for the indigent defendant the right to expert services as part of an adequate defense. The Court held that the "elementary principle [(the right of a defendant to have a fair opportunity to present his defense)], grounded in significant part on the Fourteenth Amendment's due process guarantee of fundamental fairness," ${ }^{49}$ required the state to provide an indigent defendant with a psychiatrist to aid in his defense. ${ }^{50}$ If justice cannot be equal where "simply as a result of his poverty, a defendant is denied the opportunity to participate meaningfully [in his defense]," encompass various types of nonlegal expertise as essential to an adequate defense, therefore a meaningful defense.

The United States Court of Appeals for the Eighth Circuit has extended Ake to include the appointment of a nonpsychiatric expert for a defendant in a capital case when denial of the expert would result in an unfair trial. ${ }^{52}$ Such nonpsychiatric experts should be available to provide an adequate defense when a defendant satisfies standards similar to those for psychiatrists set out in Ake. $^{53}$

B. Griffin v. Illinois and Ake v. Oklahoma: The Holdings

1. Griffin v. Illinois. In Griffin v. Illinois, ${ }^{54}$ the defendant was convicted of armed robbery in the Criminal Court of Cook County, Illinois. ${ }^{55}$ Griffin's request for a free trial transcript for use on his appeal was denied by the trial court without a hearing. ${ }^{56}$ A petition for post-conviction relief to obtain the

47. John F. Decker, Expert Services in the Defense of Criminal Cases: The Constitutional and Statutory Rights of Indigents, 51 U. CIN. L. REV. 574 (1982).

48. 470 U.S. 68 (1985).

49. Id. at 76 .

50. Id.

51. Id.

52. Little v. Armontrout, 835 F.2d 1240, 1244 (8th Cir. 1987), cert. denied, 487 U.S. 1210 (1988). For a fuller discussion of Little, see infra notes $112-25$ and accompanying text.

53. Husske v. Commonwealth, 448 S.E.2d 331 (Va. App. 1994) (extending Ake to require that defendant have access to expert assistance to respond to prosecution's DNA expert); see also infra part III (discussing the standards for appointment of experts).

54. 351 U.S. 12 (1956).

55. Id. at 13.

56. Id. at 15 . 
trial transcript was also denied and affirmed on appeal to the Illinois Supreme Court. $^{57}$ On certiorari to the state supreme court, the U.S. Supreme Court noted the importance that there be "no invidious discriminations between persons and different groups of persons." Since the central issue in the case was whether the state must provide a transcript for an indigent on the first appeal as of right, ${ }^{59}$ the defendant argued that discrimination based on financial means amounted to invidious discrimination. ${ }^{60}$ Griffin came down on the side of indigent defendants, holding that a transcript must be provided to indigent defendants at state expense. ${ }^{61}$ As an early case providing expert services for an indigent, Griffin drew criticism from the start, beginning with the concurring Justice. ${ }^{62}$ Griffin remains intact largely because of the Supreme Court's subsequent treatment of the case in Britt v. North Carolina $^{63}$ and because of the language in the Criminal Justice Act. ${ }^{64}$

In United States $v$. Devlin, ${ }^{65}$ the district court denied the defendant a free transcript of his suppression hearing. The Ninth Circuit reversed, reasoning that defense counsel should not have to rely on notes or memory to impeach witnesses and that the transcript was needed to place the defendant on an equal footing. ${ }^{66}$ Recent cases such as Devlin indicate that a transcript is a basic tool due the indigent defendant even when requested for a proceeding other than a first appeal as of right. ${ }^{67}$

57. Id.

58. Id. at 17 .

59. Id. at 15.

60. In noting protection from invidious discrimination, the Court relied on the Due Process and Equal Protection Clauses of the 14th Amendment. Id. at 18 (citing Dowd v. United States ex rel. Cook, 340 U.S. 206, 208 (1951) and Cole v. Arkansas, 333 U.S. 196, 201 (1948)).

61. Id. at 19.

62. Id. at 26 (Frankfurter, J., concurring) ("In arriving at a new principle, the judicial process is not impotent to define its scope and limits."); see also Ross v. Moffit, 417 U.S. 600 (1974). Ross is significant because it held that the state has a higher duty to provide for the defense needs of an indigent at trial than on discretionary appeal, where it had no duty to provide for such needs. Id. at 610. Thus, as an extension of the Griffin reasoning, the Ross decision protects the rights of indigents to expert services at the critical trial level.

63. 404 U.S. 226 (1971). Although the Britt Court affirmed the defendant's conviction in a narrow holding that an adequate alternative to the trial transcript had been available to the defendant, the Court declared that the Griffin line of cases establishes the mandate that indigent defendants be provided with the "basic tools" for a defense and that a transcript is such a tool. Id. at 227. The Court noted two factors critical to a determination of the need for a free transcript: (1) the value of the transcript in connection with the appeal or trial for which it is sought and (2) the availability of alternative devices that would fulfill the same functions as a transcript. Id.

64. The Criminal Justice Act of 1964,18 U.S.C. $\$ 3006$ A(e)(1) (1988), covers the defendant's right to a transcript as an expert service under the phrase "other services" and provides for its payment by the state. See infra part V.A.1.

65. 13 F.3d 1361 (9th Cir. 1994).

66. Id. at 1364 .

67. The court noted that since prosecution witnesses testified at the suppression hearing, the transcript would be required for impeachment. Id. The court also construed the transcript as a "basic tool" required under equal protection. Id. at 1363 (citing Britt v. North Carolina, 404 U.S. at 227 (1971)). 
Federal courts have scrupulously applied Griffin through $B$ ritt, ${ }^{68}$ or have relied upon statutes requiring the provision of transcripts. ${ }^{69}$ Generally the emphasis of the courts is on whether the dictates of fairness require that the indigent defendant be provided with a free transcript and whether this would help level the playing field between the indigent and the government. ${ }^{70}$ However, many cases seem to apply grants of free transcripts for an appeal on an ad hoc basis. ${ }^{71}$

As for retrials, in King $v$. White, ${ }^{72}$ the district court held that whether the indigent defendant handling his case pro se was entitled to a transcript of the first trial depended on whether there was an "adequate alternative." 73 In this case, the court held that the defendant had been repeatedly offered a continuance in order to obtain the transcript. The continuance, the court held, would have enabled the defendant to obtain the transcript if the defendant had accepted. ${ }^{74}$ Thus, there was no error when the defendant declined the court's offer.

2. Ake v. Oklahoma. In Ake v. Oklahoma, ${ }^{75}$ Justice Marshall began the Court's discussion of the equal protection and due process rights of an indigent with a citation to Griffin. ${ }^{76}$ The Court held that the state must provide access to psychiatric assistance for the indigent defendant who has made a preliminary showing that his "sanity at the time of the offense" is likely to be a "significant factor" at trial. ${ }^{77}$ In this case, defendant Ake raised an insanity defense to his capital murder charge prior to trial. ${ }^{78}$ Ake's counsel made a motion requesting

68. See, e.g., United States v. Pulido, 879 F.2d 1255, 1256-58 (5th Cir. 1989) (finding the denial of an indigent defendant's request for a copy of a transcript of mistrial prior to second trial to be reversible error); Tague v. Puckett, 874 F.2d 1013 (5th Cir. 1989) (holding that witnesses' statements and limited access to the court reporter during the second trial do not provide adequate substitutes for a transcript).

69. See, e.g., United States v. Johnson, 584 F.2d 148, 157 (6th Cir. 1978) (citing 18 U.S.C. \$ 3006A(e)(1) (1988)); United States v. Mosiman, 604 F. Supp. 1003, 1013 (E.D. Wis. 1985) (stating that a criminal defendant's right to a transcript is govemed by statute although denying the present request).

70. See United States v. Bari, 750 F.2d 1169, 1182 (2d Cir. 1984) (holding that an indigent defendant should be able to obtain daily transcripts at government expense when the government was receiving daily transcripts).

71. See Colon v. Smith, 723 F. Supp. 1003 (S.D.N.Y. 1989) (holding that the defendant suffered no harm from being denied daily trial transcripts where the trial would be a "relatively simple one" and where the court reporter could read back statements).

72. 839 F. Supp. 718 (C.D. Cal. 1993).

73. Id. at 723 (interpreting the adequate alternative requirement as required by the second prong of Britt v. North Carolina, 404 U.S. 226 (1971) as explained in Bounds v. Smith, 430 U.S. 817, 822 n.8 (1971)).

74. Id.

75. 470 U.S. 68 (1985).

76. Id. at 76 .

77. Id. at 83 .

78. Id. at 72 . 
psychiatric assistance. Relying on United States ex. rel. Smith v. Baldi ${ }^{79}$ the trial court denied the motion.

At trial, none of Ake's expert witnesses could testify to Ake's sanity or lack thereof at the time of the offense. ${ }^{80}$ Thus, Ake had no expert witnesses who could raise a reasonable doubt as to the prosecution's evidence of his sanity. The jury found Ake sane and guilty on all counts, and, as a result, Ake was given the death penalty. ${ }^{81}$ On appeal, the Oklahoma Court of Criminal Appeals affirmed the conviction. The court rejected the argument that Ake was an indigent defendant who was entitled to state-funded psychiatric assistance in the capital case as a constitutional right to effective assistance of counsel. ${ }^{82}$

The Supreme Court reversed and remanded the case for a new trial. ${ }^{83}$ The Court decided the case on the requirement that the state provide "meaningful access to justice," 84 premised on the Court's goal to ensure that indigent defendants have "an adequate opportunity to present their claims fairly within the adversary system." ${ }^{85}$ According to the Ake Court, "the state must, at a minimum, assure the defendant access to a competent psychiatrist who will conduct an appropriate examination and assist in evaluation, preparation, and presentation of the defense." ${ }^{86}$ Ake stands for a guarantee ${ }^{87}$ of competent psychiatric assistance ${ }^{88}$ to accomplish the above purposes. ${ }^{89}$ The Court's heavy reliance on the rationale of evenhanded and equal justice for the indigent leaves open the implication that psychiatric and nonpsychiatric experts are indispensable ${ }^{90}$ in capital and noncapital cases and should not be so difficult for indigents to secure. ${ }^{11}$

79. 344 U.S. 561 (1953) (holding that the state's refusal to appoint an independent expert did not deny the indigent his due process rights).

80. Ake, 470 U.S. at 72.

81. Id. at 73 .

82. Ake v. Oklahoma, 663 P.2d 1 (Okla. Crim. App. 1983), rev'd, 470 U.S. 68 (1985).

83. Ake, 470 U.S. at 87.

84. Id. at 77 .

85. Id. (citing Ross v. Moffitt, 417 U.S. 600, 612 (1974)).

86. Id. at 83 .

87. See Cowley v. Stricklin, 929 F.2d 640, 644 (11th Cir. 1991) (holding that the good fortune of finding a psychologist who will volunteer is not an adequate substitute for an indigent's right to a defense psychologist under $A k e$ ).

88. In Clisby v. Jones, 907 F.2d 1047 (11th Cir.), vacated en banc, 920 F.2d 720 (11th Cir. 1990), the court, relying on Ake, noted that indigents ought to have the same kind of assistance as the wealthy as a matter of fairness but that both types of defendants may get negligent help and that malpractice issues are separate from right to expert issues. Id. at 1050.

89. Recent court decisions that have employed Ake generally hold that where the defendant adequately satisfies the threshold showing of mental condition as a substantial factor, the guarantee of psychiatric assistance is implicated. See, e.g., Dunn v. Roberts, 963 F.2d 308 (10th Cir. 1992) (holding that the defendant's showing was thorough and ample to establish the requisite close question regarding the defendant's mental condition and that the trial court's denial of funds for an expert on the effects of battered women's syndrome prevented the defendant from presenting evidence which fairly reflected on her mental condition and affirming the granting of habeas corpus relief).

90. See infra part IV.

91. For a full treatment of the Ake decision and for further background, see Paul S. Appelbaum, In the Wake of Ake: The Ethics of Expert Testimony in an Advocate's World, 15 BULL. AM. ACAD. PSYCHIATRY \& L. 15 (1987); Karen Frances Clark, Criminal Procedure-Narrowing the Rights of Future 


\section{Caldwell v. Mississippi: Supreme Court Limitations on Expert Services for the Indigent}

The Ake decision did not specifically create a scheme for the appointment of nonpsychiatric experts in capital or noncapital cases. The Court's reliance on the Fourteenth Amendment's "guarantee of fundamental fairness" 92 and its determination to provide the indigent with "access to the raw materials integral to the building of an effective defense" 13 would seem to require consistent application to nonpsychiatric experts in both capital and noncapital cases where a defendant's "fair opportunity to present his defense" Prior to Ake, lower courts had ruled that nonpsychiatric experts were constitutionally available to indigents. ${ }^{95}$ Immediately following the Ake decision, however, lower courts often narrowed Ake to its facts, limiting the indigent's opportunity to use state-funded expert witnesses to psychiatric experts only. ${ }^{96}$

In Caldwell v. Mississippi ${ }^{97}$ decided shortly after Ake, Caldwell was charged with capital murder. Prior to trial, Caldwell asked for the appointment of a criminal investigator, a fingerprint expert, and a ballistics expert. The trial court denied his requests. ${ }^{98}$ The state supreme court affirmed the denial of experts because the requests were accompanied by no showing as to their reasonableness. ${ }^{99}$ Given that Caldwell "offered little more than undeveloped assertions" that the requested assistance of a criminal investigator, a fingerprint expert, and

Indigent Criminal Defendants in the Name of Due Process, 16 MEM. ST. U. L. REV. 417 (1986); Donald H. Dubia, The Defense Right to Psychiatric Assistance in Light of Ake v. Oklahoma, ARMY LAW. 15 (1987); David A. Harris, Ake Revisited: Expert Psychiatric Witnesses Remain Beyond Reach for the Indigent, 68 N.C. L. REV. 763 (1990); Stephen Rachlin, From Impartial Expert to Adversary in the Wake of Ake, 16 BULL. AM. ACAD. PSYCHIATRY \& L. 25 (1988); C. Robert Showalter \& W. Lawrence Fitch, Objectivity and Advocacy in Forensic Psychiatry After Ake v. Oklahoma, 15 J. PSYCHIATRY \& L. 177 (1987); Susan S. Brown, Note, After Ake: Implementing the Tools of an Adequate Defense, 7 PACE L. REv. 201 (1986); Mark P. Goodman, Note, The Right to a Partisan Psychiatric Expert: Might Indigency Preclude Insanity?, 61 N.Y.U. L. REv. 703 (1986); Marion Ty Rutter, Note, Ake v. Oklahoma: A Question of Experts, 12 OKLA. CITY U. L. REV. 385 (1987); Michael James Todd, Note, Criminal Procedure-Due Process and Indigent Defendants: Extending Fundamental Fairness to Include the Right to Expert Assistance, 29 How. L.J. 609 (1986); West, supra note 46; A. Michelle Willis, Note, NonPsychiatric Expert Assistance and the Requisite Showing of Need. A Catch-22 in the Post-Ake Criminal Justice System, 37 EMORY L.J. 995 (1988).

92. Ake v. Oklahoma, 470 U.S. 68,76 (1985).

93. Id. at 77.

94. Id. at 76.

95. See, e.g., Williams v. Martin, 618 F.2d 1021 (4th Cir. 1980) (forensic pathologist); People v. Watson, 221 N.E.2d 645 (Ill. 1966) (handwriting expert).

96. See Ex parte Grayson, 479 So. 2d 76, 82 (Ala.), cert. denied, 474 U.S. 865 (1985) ("[T]here is nothing contained in the Ake decision to suggest that the United States Supreme Court was addressing anything other than psychiatrists and the insanity defense.").

97. 472 U.S. 320 (1985).

98. Id. at 323 n.1.

99. Id. 
a ballistics expert would be beneficial, the U.S. Supreme Court found no deprivation of due process in the trial court's denial of these requests. ${ }^{100}$

Recent court decisions, such as Moore v. Kemp, ${ }^{101}$ relying on Caldwell, note that if the requisite standard of need were shown with respect to expert requests, nonpsychiatric experts would be granted on the same basis that psychiatric experts are granted in Ake. In Moore, the court interpreted Caldwell and $A k e$ to mean that a defendant, in order to get a state-funded expert, must show that a reasonable probability exists that an expert would be of assistance to the defense and that denial thereof would result in a fundamentally unfair trial. $^{102}$ The Supreme Court still has not clearly addressed the need to appoint a nonpsychiatric expert for an indigent defendant.

\section{III}

\section{Substantive and Procedural Concerns: The Standard For APPOINTMENT OF EXPERTS FOR THE INDIGENT DEFENDANT}

\section{A. Little v. Armontrout. The Importance of the Nonpsychiatric Expert}

In Caldwell, ${ }^{103}$ the Court "did not reject Caldwell's argument that an expert may be constitutionally required on issues other than sanity,"104 but instead stated that the petitioner had not presented a strong enough case. ${ }^{105}$ For example, Caldwell did not specifically explain why the ballistics expert was necessary, but he nonetheless baldly asserted the need for aid. ${ }^{106}$ State $^{107}$ and federa ${ }^{108}$ courts subsequent to Caldwell have noted the importance of nonpsychiatric experts for an indigent and, as a result, have found defendants to be entitled to nonpsychiatric experts upon a valid showing of reasonable need.

Unfortunately, many courts focus on the specificity of the showing of need. In United States $v$. Gadison, ${ }^{109}$ for example, the defendant filed a motion under 18 U.S.C. section $3006 \mathrm{~A}(\mathrm{e})(1)$ for the appointment of a private investigator at government expense. The circuit court upheld denial of the request, noting that counsel had not "ferreted out information through his own efforts which was

100. Id:; see infra part III (discussing the standard of need).

101. 809 F.2d 702 (11th Cir.) (en banc), cert denied, 481 U.S. 1054 (1987).

102. Id. at 712 .

103. 472 U.S. 320 (1985).

104. Kordenbrock v. Scroggy, 919 F.2d 1091, 1104 (6th Cir. 1990) (citing Caldwell, 472 U.S. at 323 n.1).

105. Id.

106. Caldwell, 472 U.S. at 323 n.1.

107. State v. Coker, 412 N.W.2d 589, 593 (Iowa 1987) (expert for defense of intoxication); see also People v. Dickerson, 606 N.E.2d 762, 765 (Ill. 1992) (handwriting expert); In re Cannady, 600 A.2d 459 (N.J. 1991) (expert on battered woman syndrome); McBride v. State, 838 S.W.2d 248, $250-52$ (Tex. Crim. App. 1992) (en banc) (investigator/chemist to inspect cocaine).

108. See Little v. Armontrout, 835 F.2d 1240 (8th Cir. 1987) (en banc), cert. denied, 487 U.S. 1210 (1988).

109. 8 F.3d 186 (5th Cir. 1993). 
likely to lead to the discovery of relevant evidence." 110 To justify the authorization of an investigator, the court held, there must be a showing of true "specificity" that the investigator is necessary. ${ }^{111}$

Little v. Armontrout ${ }^{12}$ is the leading federal case focusing on the importance of nonpsychiatric experts. In Little, the victim was raped in her apartment by an assailant who wore one of the victim's blouses on his head. ${ }^{113}$ The victim did not inform the attending policewoman but later told her sister that the blouse slipped from the assailant's face for between two and sixty seconds, allowing her to see the man's face. ${ }^{114}$ Two days after the attack, the victim was hypnotized by a police officer in the hope that the victim's memory of the assailant would be enhanced. The victim subsequently identified Little from a photo array and picked him out of a lineup as her assailant. ${ }^{115}$

At trial, the only substantial issue was identification of the assailant. ${ }^{116}$ Witnesses testified, ${ }^{117}$ and the jury found Little guilty of rape and sentenced him to twenty-five years in jail. ${ }^{118}$ The Missouri Supreme Court affirmed. ${ }^{119}$ Little argued that he could not prove that improper suggestion had prejudiced his case because the public defender's office could not afford to hire its own hypnosis expert. ${ }^{120}$ The state court's response was that a "resourceful lawyer" would not be helpless in obtaining expert information at a nearby university at little or no expense. ${ }^{121}$

On appeal, the Eighth Circuit reversed. The court based its rationale on Ake and Caldwell and in an oft-quoted passage ${ }^{122}$ declared:

There is no principled way to distinguish between psychiatric and nonpsychiatric experts. The question in each case must be not what field of science or expert

110. Id at 191.

111. Id. The defendant had been charged with conspiracy to distribute more than 50 grams of cocaine base. The court focused on factors such as a failure to show that prospective witnesses existed that would make the court-appointed investigator necessary, a difficult reasoning to accept when the very purpose of an investigator may be to locate witnesses who exist but are unknown.

112. 835 F.2d 1240 (8th Cir. 1987), cert. denied, 487 U.S. 1210 (1988).

113. Id. at 1241 .

114. Id.

115. Id. at 1242.

116. Id.

117. A maintenance man working in the area the night of the assault testified that he saw a man resembling Little in the area but, under cross-examination, admitted he was unsure of the identification. Because of the maintenance man's doubt about his own ability to make a correct identification, he was hypnotized. Defendant Little and several alibi witnesses testified that Little was 78 miles away in another town when the crime took place. Id.

118. Id.

119. State v. Little, 674 S.W.2d 541 (Mo. 1984) (en banc), cert. denied, 470 U.S. 1029 (1985).

120. Little, 835 F.2d at 1242.

121. Little, 674 S.W.2d at 544.

122. In Kordenbrock v. Scroggy, 919 F.2d 1091, 1104 (6th Cir. 1990) (citing Little, 835 F.2d at 1243), the court noted that no circuit has disagreed with the principle espoused by the Eighth Circuit that the question of expert assistance should turn on "how important the scientific issue is in the case." 
knowledge is involved, but rather how important the scientific issue is in the case, and how much help a defense expert could have given. ${ }^{123}$

The court concluded that Little demonstrated that an expert in hypnosis would have substantially aided in his defense and that the denial of an expert "would and did have a material impact on his trial."124 The Little decision, holding that the nonpsychiatric experts were required for an "adequate defense," was clearly influenced by the principle of fundamental fairness upon which $A k e$ is grounded. ${ }^{125}$

State courts have also grappled with the use of nonpsychiatric experts. In Ohio $v$. Wolf, ${ }^{126}$ the defendant was convicted of aggravated murder, for enclosing his wife in a plastic bag after an argument and allowing her to asphyxiate. In an unpublished opinion, the apellate court upheld the trial court's denial of the defendant's request for an investigator ${ }^{127}$ and a laboratory expert. ${ }^{128}$ At trial, the defendant had also sought a pathologist based on the absence of factual support in the autopsy that asphyxiation was the cause of death. The appellate court reversed the defendant's conviction on the aggravated murder count of the indictment due to the trial court's refusal to provide an expert pathologist. The appellate court held that the defendant must be provided with the opportunity to establish that the death did not physiologically occur as the prosecution said it did and that only an expert pathologist could competently present evidence on how superficial blows to the head can cause death. ${ }^{129}$ The court noted that an expert may have testified that sufficient force was used by the defendant to merit a finding that he acted in "sudden passion" or a "sudden fit of rage." 130

With nonpsychiatric experts as with psychiatric experts, courts rigorously impose the requirement that there be more than a mere possibility of assistance

123. Little, 835 F.2d at 1243 . The court went on to say that no line could be drawn for due process purposes that would distinguish between capital and noncapital cases. The defendant's interest in staying alive is greater than avoiding a prison term, but the interest of the defendant in avoiding the prison term still outweighs the state's interest in avoiding a relatively small expense. Id.

124. Id. at 1244 .

125. As one commentator has noted, $A k e$ 's nonresponsiveness to other types of experts may create the necessary limitation of $A k e$ to its facts, the right to a psychiatrist for an insanity defense. See West, supra note 46 , at 1338 . The author also notes that given the importance of nonpsychiatric experts to accurate fact finding, the $A k e$ reasoning requires that experts be made available to indigent defendants as well as the prosecution when they appear reasonably necessary to assist counsel in their preparation. Id. at 1340 (emphasis added) (citing United States v. Pope, 251 F. Supp. 234, 241 (D. Neb. 1966)).

126. No. 91-L-096, 1992 WL 366985 (Ohio Ct. App. Dec. 11, 1992); see also, Terry v. Rees, 985 F.2d 283 (6th Cir. 1993) (holding denial of a pathologist denied the defendant the opportunity to present an effective defense, but concluding the denial was harmless error).

127. The court denied the investigator on the ground that only one victim and one defendant were involved, and the magnitude of the case, therefore, did not warrant the expert. Wolf, 1992 WL 366985 , at $* 4$.

128. Defendant sought an independent analysis of the truck. He alleged his wife died as the result of blows and not asphyxiation caused by being placed in a plastic bag; had asphyxiation been the cause, the victim would have defecated in the truck. Id.

129. Id at $* 5$.

130. Id 
from the expert. In Yohey $v$. Collins, ${ }^{131}$ the court noted that an expert such as a ballistics expert should be provided only if the evidence is "both critical to the conviction and subject to varying expert opinion."132 A lack of such showing on the part of the defendant warranted a denial of the expert. ${ }^{133}$

\section{B. The "Significant Factor at Trial" Test: A Showing of Need}

On the one hand, in United States v. Bagley, ${ }^{134}$ Justice Marshall's dissenting opinion admitted that the Supreme Court had not required the appointment of investigators (as nonpsychiatric experts) "who will assure that the defendant has an opportunity to discover every existing piece of helpful evidence."135 On the other hand, however, Ake held that when the defendant's sanity was "likely to be a significant factor at trial," a psychiatric expert must be appointed for an indigent defendant. ${ }^{136}$

Federal courts have relied heavily on the "significant factor" language of Ake when reviewing requests for psychiatric assistance. ${ }^{137}$ Requests for psychiatric assistance are usually denied for lack of a showing of mental state as a significant factor. ${ }^{138}$ Few published opinions grant reversals based on the trial court's failure to appoint a psychiatric expert. ${ }^{139}$ Since $A k e$, the courts have emphasized that the burden rests on the defendant seeking the expert service to satisfy the court that the relevant expert testimony is necessary to present an adequate defense. ${ }^{140}$ The decision to appoint the expert is

131. 985 F.2d 222 (5th Cir. 1993).

132. Id. at 227 (internal quotations omitted).

133. The court also rejected the defendant's argument that the court's denial of experts rendered counsel ineffective by forcing his attorney to choose whether or not to use his own money for a defense. Id.

134. 473 U.S. 667 (1985).

135. Id. at 695 (Marshall, J., dissenting).

136. Ake v. Oklahoma, 470 U.S. 68,74 (1985).

137. See, e.g., Clark v. Dugger, 834 F.2d 1561, $1564-65$ (11th Cir. 1987), cert. denied, 485 U.S. 982 (1988) (holding that a murder defendant had no constitutional right to appointment of a psychiatric expert to make confidential reports to the defendant's counsel where no showing was made that sanity would be a significant issue at trial); Messer v. Kemp, 831 F.2d 946, 964 (11th Cir. 1987), cert. denied, 485 U.S. 1029 (1988), (Defendant "never said, much less articulated a factual basis for believing, that his sanity at the time of the offense would be a significant factor at trial," and counsel made no mention of the defendant's mental state.); see also Moore v. Kemp, 809 F.2d 702, 710-12 (11th Cir.), cert. denied, 481 U.S. 1054 (1987) (holding that to demonstrate constitutional necessity, the defendant must show not only that the expert would assist the defense, but also that denial of the expert would result in an unfair trial, and that the defendant must furnish the court with specifics about the State's case and provide a substantial basis for any defense for which he desires the expert's help).

138. See, e.g., Volanty v. Lynaugh, 874 F.2d 243 (5th Cir.), cert. denied, 493 U.S. 955 (1989); United States v. Fazzini, 871 F.2d 635, 637-39 (7th Cir.), cert. denied, 493 U.S. 982 (1989); Cartwright v. Maynard, 802 F.2d 1203 (10th Cir. 1986).

139. See Cowley v. Stricklin, 929 F.2d 640, 642-45 (11th Cir. 1991) (overturning the state trial court's failure to provide psychiatric assistance when an ample showing of a significant insanity defense was made); see also Liles v. Saffle, 945 F.2d 333, 335-40 (10th Cir. 1991), cert. denied, 112 S. Ct. 956 (1992).

140. See, e.g., United States v. Nichols, 21 F.3d 1016, 1018 (10th Cir. 1994) (holding that even though defendant seeking to establish a defense of entrapment by estoppel had an I.Q. of only about 75, the burden is still on the defendant to show that the services of a psychological expert are "necessary to an adequate defense" (citing United States v. Greschner, 802 F.2d 373, 376 (10th Cir. 1986))); United 
completely within the discretion of the judge. ${ }^{141}$ An appellate court can reverse the decision to appoint an expert only if the trial court abused its discretion. ${ }^{142}$

Some courts appear to be blending economic arguments with the standard for a showing of need. In Riley v. Snyder, ${ }^{143}$ for example, the defendant was charged with conspiracy and murder in a liquor store robbery. The defendant sought appointment of an investigator to establish corroborating testimony of witnesses to establish an alibi. The court reasoned that the simplicity of the defense and prospective ability of counsel to locate witnesses negated the need for the investigator. ${ }^{144}$ However, the court also indicated that it would simply be more economical for the defendant to hire a private investigator without providing a basis for this conclusion.

State courts have similarly relied on the $A k e$ "significant factor at trial" test in granting expert services. ${ }^{145}$ However, state courts also have affirmed trial court denials of psychiatric services at state expense because no preliminary showing of need was made by the defense. ${ }^{146}$ Some state courts have applied rationales that seem to conflict with the mandates of Britt and Ake, which require the state to provide the indigent defendant with the resources necessary to meet a prosecution by the state. ${ }^{147}$

The state courts have struggled to refine $A k e$ 's threshold requirement with widely varied results. Some courts hold that both $A k e$ and due process require the appointment of experts prior to trial when it is "reasonably necessary." 148 Other courts rely on the discretion of the trial judge, who has the ability to observe the defendant firsthand. ${ }^{149}$

States v. St. Pierre, 812 F.2d 417 (8th Cir. 1987).

141. Nichols, 21 F.3d at 1018.

142. Id.

143. 840 F. Supp. 1012 (D. Del. 1993).

144. Id. at 1036. The court reasoned that there had been no showing that defense counsel would not be able to locate possible witnesses. The court also adopted the Delaware Supreme Court reasoning that "the defense was a simple alibi .... Neither party relied upon any extensive scientific or psychiatric testimony." Id. (citing Riley v. State, 496 A.2d 997, 1017 (Del. 1985)).

145. See, e.g., State v. Coker, 412 N.W.2d 589, 593 (Iowa 1987); People v. Vale, 519 N.Y.S.2d 4, $5-7$ (N.Y. App. Div. 1987).

146. See, e.g., State v. Foster, 510 So. $2 d$ 717, 726-27 (La. Ct. App. 1987).

147. In State v. Searcy, 798 P.2d 914 (Idaho 1990), the court cited the dissent of Justice Rehnquist in $A k e$ and found that the insanity defense was constitutionally doubtful and that the defendant would have to prove insanity. Id. at 918 . Clearly it would be impossible for an indigent to prove an insanity defense without a grant of expert assistance.

148. See, e.g., State v. Williams, 800 P.2d 1240, 1247 (Ariz. 1987); Sommers v. Kentucky, 843 S.W.2d 879, 882-85 (Ky. 1992); State v. Parks, 417 S.E.2d 467, 471 (N.C. 1992); Washington v. State, 836 P.2d 673, 674-77 (Okla. Crim. App. 1992).

149. Gay v. State, 562 So. 2d 283, 290 (Ala. Crim. App. 1990) (citing Bailey v. State, 421 So. 2d 1364, 1366-67 (Ala. Crim. App. 1982)). In Ake, the defendant's bizarre behavior prompted the court sua sponte to order a psychiatric exam prior to trial. However, this examination was not performed by a psychiatrist employed by the defense; it was a court-appointed psychiatrist. Ake v. Oklahoma, 470 U.S. $68,70-71$ (1985). Reliance on a judge as a firsthand observer would seem tenuous in the matter of psychiatric evaluation. 
The federal courts have also grappled with the threshold showing requirement. For example, in United States v. St. John, ${ }^{150}$ the defendant was charged with incest and sought appointment of an expert to evaluate the victim psychiatrically. ${ }^{151}$ The request was denied. The appellate court, relying on $A k e$, acknowledged the defendant's right of access to the materials needed to construct an effective defense, including expert witnesses. ${ }^{152}$ The court, however, held that defendants do not have "carte blanche"153 to retain any expert, but only those experts necessary to "present claims fairly within the adversary system."154 St. John illustrated the Eighth Circuit's view of the threshold requirement: "We strike this balance by requiring that a defendant show a reasonable probability that an expert would have aided in her defense, and that the denial of an expert witness resulted in an unfair trial."155

In analyzing whether a defendant has raised an issue of sufficient significance to warrant appointment of an expert, courts are careful not to authorize "fishing expeditions." 156 Sometimes Congress ${ }^{157}$ and state legislatures ${ }^{158}$ impose statutes limiting such fishing expeditions. The defendant's showing of need must be "clear and genuine" and constitute a "close' question." must articulate a factual basis demonstrating that a defense psychiatrist is necessary; the defendant's pleading must show more than that the defendant is merely contemplating an insanity defense. ${ }^{160}$

150. 851 F.2d 1096 (8th Cir. 1988).

151. Id. at 1097-98.

152. Id. at 1098 (citing Ake, 470 U.S. at 77).

153. Id.

154. Id. (citing Ake, 470 U.S. at 77 ).

155. Id. (citing Little v. Armontrout, 835 F.2d 1240, 1244 (8th Cir. 1987)). In terms of assuring that the defendant will have every opportunity to fairly present a case within the adversary system, any effort by the courts to merely require "reasonable probability" that the expert is necessary would be a welcome departure from the sometimes constrictive juridical framework that requires a threshold showing of "insanity" as a significant factor. Particularly efficacious at ensuring the defendant every opportunity for expert services both psychiatric and nonpsychiatric is the Little court's declaration that what is important is "how much help a defense expert could have given." Little, 835 F.2d at 1243; see supra part III.A and infra part IV. In St. John, the mental capacity of the victim, not the defendant, was at issue. 851 F.2d at 1098. For a treatment of mental impairment and the criminal defendant, see generally James W. Ellis \& Ruth A. Luckasson, Mentally Retarded Criminal Defendants, 53 GEO. WASH. L. REV. 414 (1985).

156. In United States v. Alden, 767 F.2d 314 (7th Cir. 1984), the court noted that to require the government to pay for psychiatric services just because a private attorney would do so in the hope of establishing an insanity defense would be to require the government to subsidize a "fishing expedition." Id. at 318.

157. 18 U.S.C. $\S 3006$ A(e) (1988).

158. See, e.g., ARIZ. R. CRIM. P. 11.3(a), which permits trial courts to provide the defendant with experts if the court determines that reasonable grounds for an examination exist. As Arizona courts have construed this rule, it is not enough that the defendant merely contemplates insanity as a defense; the evidence must create a reasonable doubt in the court's mind as to the defendant's sanity at the time of the alleged offense. See, e.g., State v. Williams, 800 P.2d 1240, 1247 (Ariz. 1987).

159. State v. Harris, 789 P.2d 60, 68 (Wash. 1990) (citing Cartwright v. Maynard, 802 F.2d 1203, 1211 (10th Cir. 1986) (internal quotations omitted)).

160. Id. at 68; see also Messer v. Kemp 831, F.2d 946, 964-65 (11th Cir. 1987), cert. denied, 485 U.S. 1029 (1988) (finding a need for more than "naked demands"). 
State courts have denied requests for nonpsychiatric experts with unfortunate zeal. ${ }^{161}$ Federal courts have also been reluctant to grant requests for other types of experts. ${ }^{162}$ For example, in United States v. Valverde, ${ }^{163}$ the defendant was charged with conspiring to escape while in federal custody. ${ }^{164}$ Valverde had met with an undercover deputy who had "secretly recorded the conversations," which included statements that Valverde later admitted were in reference to a scheme to attempt escape. ${ }^{165}$ Valverde requested expert testimony in the form of a linguistic expert who would have testified that the tape recorded statements were not designed to influence law enforcement officers. ${ }^{166}$ The trial court denied the request. ${ }^{167}$

On appeal, the Eighth Circuit affirmed. Although the court noted that case law required the appointment of an expert if needed for an adequate defense, ${ }^{168}$ the burden of establishing this need was on the defendant, ${ }^{169}$ and the court concluded that it did not believe that the proposed expert witness would have assisted the trier of fact. Opinions such as Valverde represent the ad hoc balancing done by the courts that makes it difficult for an indigent to secure experts when they might in fact be reasonably helpful.

Trial courts are generally given vast discretion in determining whether a satisfactory showing of need has been made by the defense in requesting an expert. It is often within the trial court's discretion to determine whether the appointment would be needless, wasteful, or extravagant. ${ }^{170}$ Curiously such courts articulate the importance of providing expert services for the indigent at length and concede that the opportunity to prepare a defense is a basic tool, but then diffuse the importance of experts by holding that an expert need not be

161. See, e.g., Siebert v. State, 562 So. 2d 586, 588-90 (Ala. Crim. App. 1989) (polling expert), cert. denied, 498 U.S. 963 (1990); Williamson v. State, 812 P.2d 384, 395-96 (Okla. Crim. App. 1991) (hair comparison and serology), cert. denied, $112 \mathrm{~S}$. Ct. 1592 (1992).

162. See, e.g., Scott v. Louisiana, 934 F.2d 631, 633 (5th Cir. 1991) (denial of ballistics expert); United States v. Greschner, 802 F.2d 373, 376-77 (10th Cir. 1986) (denial of penologist), cert. denied, 480 U.S. 908 (1987); United States v. Minor, 756 F.2d 731, 737 (9th Cir.) (denial of travel for investigator), vacated on other grounds, 474 U.S. 991 (U.S. 1985), rev'd in part on other grounds, 783 F.2d 154 (9th Cir. 1986); United States v. Walborn, 730 F.2d 192, 194 (5th Cir.) (denial of fingerprint expert), cert. denied, 469 U.S. 842 (1984). Contra Terry v. Rees, 985 F.2d 283, 284-85 (6th Cir. 1992) (error, but harmless, to not appoint an independent expert pathologist for the defense to determine the cause of death).

163. 846 F.2d 513 (8th Cir. 1988).

164. Id. at 514 .

165. Id. at 515 .

166. Id. at 516 .

167. Id.

168. Id. (citing United States v. One Feather, 702 F.2d 736, 738 (8th Cir. 1983)).

169. Id.; see also United States v. Sailer, 552 F.2d 213, 215-16 (8th Cir.), cert. denied, 431 U.S. 959 (1977).

170. Scott v. State, 593 N.E.2d 198, 200 (Ind. 1992). The court noted that a wealthy person could hire any number of people to aid in the defense, but where the court allocates funds, it is rational for the court to use discretion. Id. at n.7 (citing Magley v. State, 335 N.E.2d 811, 816 (Ind. 1975)). This standard inescapably vests the outcome of a defendant's request on the judge's financial bent. At least one court, however, has noted that the fact that funds are in limited supply is not an appropriate reason for denying access to experts and without more would be an abuse of discretion. State v. Stow, 620 A.2d 1023, 1027 (N.H. 1993). 
provided if, in the court's opinion, the expert could not show what the defendant desires. ${ }^{171}$

In cases where an indigent defendant seeks an expert, and a showing of need is at issue, courts will not reverse a denial of an expert unless there is a considerable abuse of discretion. In People v. Smith, ${ }^{172}$ the court noted that funds are available only where expert services are crucial and where financial inability will prejudice the case. The trial court had refused the request for expert services based on untimeliness and a determination that the expert service simply would not assist in the understanding of the issues in the case. ${ }^{173}$ The appellate court concluded that, even assuming that funds should have been provided, the failure to do so was harmless error. ${ }^{174}$

\section{The Mathews v. Eldridge Test: The Ultimate Social Goal of Acquitting the Innocent}

During the time that the rights of the indigent were being developed, the Supreme Court noted that "the very premise of our adversarial system is that partisan advocacy on both sides of a case will best promote the ultimate objective that the guilty be convicted and the innocent go free." ${ }^{.175}$ In $A k e$, the Court noted that in order to provide "[m]eaningful access to justice,"176 the ultimate goal of the adversary system would be to ensure that both parties are evenly matched for the trial process. ${ }^{17}$ When society fosters a system that convicts only guilty people, confidence in the legal system is preserved in the interest of the general populace and, of course, in the interest of the individual acquitted. In Ake, the Court relied on Mathews v. Eldridge ${ }^{178}$ and a threeprong balancing test: (1) the "private interest" that would be affected by the State's action; (2) the "[g]overnment's interest" that an additional due process

171. Scott, 593 N.E.2d at 200 (citing Jones v. State, 524 N.E.2d 1284, 1286 (Ind. 1988)).

172. 614 N.E.2d 1326, 1330 (Ill. App. Ct.), vacated on other grounds, 620 N.E.2d 417 (Ill. 1993).

173. The defendant sought an expert witness and DNA testing after being accused of aggravated criminal sexual assault. Id.

174. Id. at 1331. On harmless error and the standard of review, see United States v. Nichols, 21 F.3d 1016 (10th Cir. 1994); United States v. Devlin, 13 F.3d 1361 (9th Cir. 1994).

175. Pennsylvania v. Finley, 481 U.S. 551, 568 (1986) (citing Herring v. New York, 422 U.S. 853, 862 (1975)).

176. Ake v. Oklahoma, 470 U.S. 68,77 (1985).

177. Id. (citing Ross v. Moffitt, 417 U.S. 600, 612 (1974)); see also United States v. Cronic, 466 U.S. 648, 656-57 (1984). In Cronic, the Court noted that if the quality of the confrontation via the adversarial process is diminished, the right to effective assistance is diminished. Clearly, experts for the indigent are crucial to the maintenance of the adversarial system.

178. 424 U.S. 319 (1976). The Mathews test is a familiar one applied primarily in administrative law. For a general criticism of the test, see Edward L. Rubin, Due Process and the Administrative State, 72 CAL. L. REV. 1044, 1136-44 (1984). Rubin notes that under Mathews there should be a "separate theory for defining minimum procedures in administrative adjudications." Id. at 1137. Rubin also argues that to use Mathews to determine due process requirements in nonadministrative cases would produce "major dislocations in existing doctrine, since it would be very difficult to derive the components of criminal or civil trials from that framework." Id. He also notes the relative insensitivity in nonadministrative cases of procedural requirements "to the magnitude of the individual interest at stake." Id. at 1139. 
safeguard would impact; and (3) the "probable value ... of additional or substitute procedural safeguards" that are sought, and "the risk of an erroneous deprivation" of the affected interest if those safeguards are not provided. ${ }^{179}$ Courts have often used this test to resolve administrative law disputes ${ }^{180}$ and civil commitment cases. ${ }^{181}$

In Ake, the Court expanded Mathews to incorporate issues of criminal defense for the indigent. The Court noted its earlier reference to the "quasicriminal" case of Little $v$. Streater ${ }^{182}$ and moved to an application of the first prong. The Court simply noted that the criminal defendant's private interest in life or liberty was "uniquely compelling"183 and that the "interest of the individual in the outcome ... weighs heavily." 184 On the second prong, the Court concluded that the financial interest of the state was "not substantial," and noted the "compelling interest of both the State and the individual in accurate dispositions." 185 The Court focused on the third prong and concluded that psychiatry could play a "pivotal role" and "dramatically enhance[]" the "potential accuracy of the jury's determination." 186

Recent cases have also relied on the Mathews balancing test. For example, in Kordenbrock v. Scroggy, ${ }^{187}$ the Sixth Circuit noted:

[The defendant's] interest in the accuracy of the criminal proceeding-having the jury be in a position to understand the mental and psychiatric aspects of the case-outweighs the cost to the state in furnishing experts. After all, it is the state which is seeking to put the defendant to death. Compared to that cost, the cost of a psychiatric expert pales. ${ }^{188}$

Although Ake and Kordenbrock both employ the Mathews test in the context of a psychiatrist, the neutral language of the balancing of interests could easily apply to nonpsychiatric experts who often weigh heavily in the needs of the defendant. ${ }^{189}$

179. Mathews, 424 U.S. at 335.

180. See, e.g., Lively v. Bowen, 827 F.2d 268 (8th Cir. 1987). In Bowen, the court employed the Eldridge test to review the refusal of the Secretary of Health and Human Services to reconsider a determination that a claimant was no longer entitled to benefits. Id at 269.

181. See, e.g., Goetz v. Crosson, 967 F.2d 29, 33-34 (2d Cir. 1992). The Goetz court applied the Mathews test to a defendant faced with an involuntary civil commitment who had raised an $A k e$ claim. The court held that the Ake "battle of the experts" rationale did not apply, and thus the State's financial interest outweighed the defendant's private interest. Id. at 33-37.

182. Ake v. Oklahoma, 470 U.S. 68, 77 (1985) (citing Little v. Streater, 452 U.S. 1 (1981)).

183. Id. at 78 .

184. Id.

185. Id. at 79.

186. Id. at $79,83$.

187. 919 F.2d 1091 (6th Cir. 1990).

188. Id. at 1105 .

189. The American Bar Association has noted the importance of providing "investigatory, expert, and other services necessary to an adequate defense." An explanatory note explains that defense representation "may be excellent and yet valueless to the defendant if the defense requires the assistance of a psychiatrist or handwriting expert and no such services are available." AMERICAN BAR ASSOCIATION, STANDARDS FOR CRIMINAL JUSTICE $§ 5-1.4$ (2d ed. 1986). 
Some courts have noted Ake's reliance on the Mathews test but impose additional conditions on the test. For example, in State $v$. Wainwright, ${ }^{190}$ the Kansas Court of Appeals noted that the balancing test in Ake provides a test for the grant or denial of experts. Before employing the test, however, the court added the requirement that "a defendant must first clearly show that the proposed expert testimony will relate to a material issue raised in the defense." 191

\section{IV}

\section{THE ROLE OF THE EXPERT}

\section{A. Ake Revisited: The Expert as Part of the Defense Team}

Since $A k e,{ }^{192}$ undoubtedly one of the most disputed questions hinges on the role of the expert. Ake held that once the necessary showing is made, ${ }^{193}$ "the state must, at a minimum, assure the defendant access to a competent psychiatrist who will conduct an appropriate examination and assist in evaluation, preparation, and presentation of the defense." 194 The Court did not expressly reverse the earlier precedent established in Baldi, ${ }^{195}$ but rather expanded what was a very limited right based on growing concern over the protection of the rights of the indigent to an adequate defense and the corollary expert services. ${ }^{196}$ The Baldi Court simply concluded that "[p]sychiatrists

190. 856 P.2d 163, 167 (Kan. Ct. App. 1993).

191. Id at 167 . The court also noted that a denial of expert services by a lower court will not be disturbed on appeal unless prejudice to substantial rights is demonstrated. Id. (citing State v. Owens, 807 P.2d 101 (Kan. 1991)).

192. As noted supra parts II-III, the dispute over the role of the expert was brewing long before the Ake decision. In the oft-quoted case of United States v. Pope, 251 F. Supp. 234 (D. Neb. 1966), the court interpreted the fledgling Criminal Justice Act to require the appointment of experts where they "reasonably appear necessary to assist counsel in their preparation." Id. at 241 (emphasis added). Other pre-Ake courts focused on the role of experts as one of facilitating effective assistance of counsel. See, e.g., Matlock v. Rose, 731 F.2d 1236, 1242-43 (6th Cir. 1984), cert. denied, 470 U.S. 1050 (1985).

193. See supra part III.B.

194. Ake v. Oklahoma, 470 U.S. 68, 83 (1985) (emphasis added).

195. United States ex rel. Smith v. Baldi, 344 U.S. 561 (1953); see supra part I. Baldi was a somewhat ambiguous case. The defendant had been examined by a psychiatrist appointed by the court. The defendant's request for appointment of a psychiatrist was denied by the state court. The Baldi opinion does not make it clear whether the indigent defendant had no right to a psychiatric examination or psychiatric expert, or merely a limited right to be left, as $A k e$ would later declare, to the discretion of the states in the manner of implementation. Ake, 470 U.S. at 83.

196. In Baldi, "neutral" psychiatrists examined the defendant before his trial. In $A k e$, the defendant had been denied any psychiatric assistance concerning his mental state at the time of the offense. Thus, neutrality appears to be the Baldi standard which is rejected by the Ake Court. The contention that there is no constitutional right to a psychiatric examination of defendant's sanity at the time of the offense is not persuasive. Ake, 470 U.S. at 85. The Ake Court arguably expands a defendant's right to more than a "neutral" psychiatrist by saying that the Court's disagreement with the state court's reliance on Baldi is "fundamental," and that the Court has "signaled" an "increased commitment to assuring meaningful access to the judicial process." Id. The Court noted that the enhanced role of psychiatry in criminal law and the "altogether different variables" cause Baldi to no longer be limiting. Id. 
testified. That suffices."197 Today, the vestiges of Baldi exist primarily in state courts, where courts lacking resources may focus on the minimum required by $A k e .^{198}$ Some federal courts also readily dispatch complaints made by defendants after there has been expert testimony. ${ }^{199}$

In De Freece $v$. State, ${ }^{200}$ the defendant appealed a murder conviction on the grounds that the trial court erred in failing to appoint an expert to prepare an insanity defense. ${ }^{201}$ After an extensive analysis of $A k e$ and the pivotal role of psychiatry and the assistance to be provided by psychiatrists, the court reversed. The reversal was based largely on the fact that since sanity was the only contested issue, failure to appoint an expert may have contributed to the verdict. $^{202}$ The court also noted that more than just simply favorable psychiatric testimony is required to satisfy $A k e .^{203}$ Counsel may require other aid such as in interpretation of records or conclusions more in keeping with the idea of the expert as a member of the defense team. ${ }^{204}$

\section{B. Neutral, Partisan, and Independent Experts}

While leaving some discretion to the states ${ }^{205}$ in implementing the holding, the rationale of $A k e$ clearly requires more than a "neutral" psychiatrist. $^{206}$ However, many courts since $A k e$ have imposed grants for psychiatric assistance that amount to little more than "neutral" assistance. ${ }^{207}$ Post- $A$ ke

197. 344 U.S. at 568.

198. For example, in People v. Wright, 594 N.E.2d 276 (Ill. 1992), cert. denied, 479 U.S. 1101 (1993), the defendant who was convicted of burglary, attempted murder, murder, and other crimes, had been hospitalized for 15 years as the result of a "shoe fetish." Two psychiatrists had been appointed by the court at trial. Id. at 279 . Later, when possible mitigating evidence was discovered in a post-conviction proceeding, the court interpreted $A k e$ to hold that the defendant was entitled to one and only one psychiatrist. Id. at $\mathbf{2 8 6 - 8 7}$. This is characteristic of courts which focus more on minimizing $A k e$ rather than providing adequate tools for the defense.

199. In Brown v. Doe, 803 F. Supp. 932, 941 (S.D.N.Y. 1992), the court noted that the defendant complained only after the expert, one of the defendant's own choice and paid for by the state, testified that the defendant labored under no mental disease or defect which would prevent him from understanding.

200. 848 S.W.2d 150 (Tex. Crim. App.) (en banc), cert. denied, 114 S. Ct. 284 (1993).

201. Defense counsel had sought an expert who "would be a member of the defense team, would be available for helping preparation of the case, preparation of cross examination, deciding which tests were needed, range and form, that sort of thing, as well as being present during trial to help the defendant." Id. at 152. The trial court's response was that one expert had already been appointed (who had gone on record as supporting the State's position) and another was not necessary. Id.

202. Id at 160 .

203. The court noted that even though adequate cross-examination was conducted this does not mean that an even more effective job could have been done with an expert's assistance. Id. at 159 .

204. Id. at $160-61$.

205. Ake, 470 U.S. at 85.

206. Many states have adopted the Arkansas approach, which holds that a defendant's right to an examination under $A k e$ is adequately protected by an examination at the state hospital which is uninvolved in criminal prosecutions. See Coulter v. State, 804 S.W.2d 348, 355 (Ark.), cert. denied, 112 S. Ct. 102 (1991). Generally, such psychiatric exams are statutorily provided. See ARK. CODE ANN. \$-2-305 (Michie Supp. 1993).

207. In Glass v. Blackburn, 791 F.2d 1165, 1168 (5th Cir. 1986), cert denied, 481 U.S. 1042 (1987), Louisiana had established a two-member "sanity commission" and only one of the members testified to the sanity of the defendant at the time of the offense. The court denied the defendant's claim to a 
courts have in fact generally favored appointments from the public sector. ${ }^{208}$ In United States $v$. Rinchack, ${ }^{209}$ the Eleventh Circuit held that once the required showing of need was made, the psychiatrist could be "any other qualified psychiatrist." 210 This term included court-appointed and privately retained psychiatrists. ${ }^{211}$

Neutral or impartial experts have posed a number of problems since the Ake decision. In Granviel v. Lynaugh, ${ }^{212}$ the defendant requested the appointment of a psychiatrist and requested that the psychiatrist be unavailable to the prosecution or the court. Since state law required disclosure to all parties of any appointed psychiatrist's report, the request was denied. ${ }^{213}$

The Granviel court appointed a disinterested expert whose report would be available to the prosecution and defense. ${ }^{214}$ On appeal, the Fifth Circuit held that Granviel's Ake rights were not violated. According to the court, the sole purpose of the expert was to enable him to form an opinion on the defendant's mental capacity. ${ }^{215}$ The "disinterested qualified expert" was not to be a private consultant for either party but to serve the court. ${ }^{216}$ The court also denied the defendant's claims that his fifth amendment right was violated by

violation of $A k e$ rights based on the ground that no independent psychiatrist was requested, although it could have been. Id. at 1168-69. This dubious rationale seems to violate the spirit of the Ake holding.

208. In Buttrum v. Black, 721 F. Supp. 1268 (N.D. Ga. 1989), aff d, 908 F.2d 695 (11th Cir. 1990), the court emphasized that appointment of a psychiatrist from the public sector is not per se unreasonable, and due process does not require a private psychiatrist. Id. at 1311-12.

209. 820 F.2d 1557 (11th Cir. 1987). Prior to trial, the defendant claimed he was incompetent to stand trial due to an earlier accident. Id. at 1561. Thirty minutes prior to the scheduled competency hearing, Rinchack sought appointment of a psychiatrist at government expense under 18 U.S.C. $\S 3006 \mathrm{~A}(\mathrm{e})$. This request was denied. Id. at 1562 . Rinchack was found competent and was later convicted at trial. On appeal, the Eleventh Circuit affirmed the trial court's discretionary refusal to appoint Rinchack an expert on two grounds: (1) the request was not timely and (2) the services were not necessary to an adequate defense. $I d$. at 1563-64.

210. Id. at 1565 .

211. Id. (citing United States v. Chavis, 476 F.2d 1137, 1143 (D.C. Cir. 1973)). The court noted that the issue does not revolve around what technical provision the expert was appointed under but, rather, whether the necessary assistance was received. Id.

212. 881 F.2d 185 (5th Cir. 1989), cert. denied, 495 U.S. 963 (1990).

213. Id. at 191 .

214. Id. at 190-91. Before the trial began, the state amended $\$ 46.02$ of the Texas Code of Criminal Procedure, which provided that disinterested, qualified experts such as court-appointed psychiatrists were prohibited from testifying about statements made by the defendant. After the amendment, a copy of the "disinterested" psychiatrist's report had to be furnished to the court and to opposing counsel. TEX. CODE CRIM. PROC. ANN. art. 46.02 $\$ 3$ (d) (West 1992).

215. Granviel, 881 F.2d at 191-92. The court apparently justified its findings on the purpose of the expert on the grounds that the "ability [of the defendant] to uncover the truth concerning his sanity is not prejudiced by the appointment of a court-ordered psychiatrist." Id.; see also Steven A. Saltzburg, Privileges and Professionals: Lawyers and Psychiatrists, 66 VA. L. REV. 597 (1980). More in keeping with $A$ ke's attempt to provide the defendant with an "adequate defense" in every respect would be to restrict the findings of the defense psychiatrist to avoid creation of incriminating evidence.

216. Granviel, 881 F.2d at 191. Justices Marshall and Brennan would have granted certiorari in Granviel on the question of whether an indigent criminal defendant's constitutional right to psychiatric assistance in preparing an insanity defense is satisfied by court appointment of a psychiatrist whose examination report is available to both the defense and prosecution. Granviel v. Texas, 495 U.S. 963 (1990) (Marshall \& Brennan, JJ., dissenting from denial of petition for writ of certiorari). Nevertheless, the precise scope of $A k e$ 's requirement of psychiatric assistance remains an open issue. 
disclosure of the report ${ }^{217}$ and that his sixth amendment right was violated because no independent expert was appointed. ${ }^{218}$

In State v. Richards, ${ }^{219}$ the defendant appealed his conviction of first-degree murder in part because he was denied an independent psychiatrist. A state psychiatrist was used by the prosecution, and this expert was to make his services and opinions available to the defendant. The trial court rejected the defendant's request and held that no claim was made that the psychiatrist was incompetent but only that the expert was "neutral."220 The Supreme Court of Minnesota affirmed the denial, noting that a defendant cannot complain that he was denied access to a psychiatrist because he chose not to take advantage of the available assistance.

Courts have followed the Granviel rationale ${ }^{221}$ and seem to focus more on $A k e$ 's limitation on services for the indigent, noting that the defendant's right does not include the "right to choose a psychiatrist of his personal liking or to receive funds to hire his own."222 If not totally incorrect, these cases certainly misread the emphatic message of Ake. The emphasis in Ake was on providing an expert who would "assist in evaluation, preparation, and presentation of the defense."223 Although some courts have claimed that due process implications are satisfied by appointment of a neutral or independent psychiatrist ${ }^{224}$ (or arguably another type of expert), a better reading of $A k e$ would hold that there is no such thing as a neutral expert for the defense. ${ }^{225}$

Part of the confusion in lower courts revolves around a characterization of the expert's role (whether psychiatric or nonpsychiatric) as an assistant to defense counsel in preparation and presentation of the defense. ${ }^{226}$ Thus, although some lower courts have held that proper assistance for the defense under $A k e$ is satisfied even when the psychiatric report is revealed to the court

217. Granviel, 881 F.2d at 190. Relying on Buchanan v. Kentucky, 483 U.S. 402 (1987), the court held the privilege was waived by raising sanity issues. Id.

218. Granviel, 881 F.2d at 190 (holding that the defendant's 6th amendment rights had not yet attached).

219. 495 N.W.2d 187 (Minn. 1992).

220. Id. at 198. MINN. R. CRIM. P. 20.02 provides that the court may submit a defendant asserting a mental illness defense to an examination by a court-appointed psychiatrist.

221. See, e.g., Silagy v. Peters, 905 F.2d 986, 1013 n.22 (7th Cir. 1990) (finding no constitutional right to select a psychiatrist of personal liking, citing Ake v. Oklahoma, 470 U.S. 68,83 (1985)), cert. denied, 498 U.S. 1110 (1991).

222. Ake v. Oklahoma, 470 U.S. 68,83 (1985).

223. Id.

224. See, e.g., Clisby v. Jones, 960 F.2d 925, 928-34 (11th Cir. 1992).

225. Smith v. McCormick, 914 F.2d 1153, 1158 (9th Cir. 1990) (reading Ake to reject the idea of a "neutral" court-appointed psychiatrist).

226. See, e.g., Bruce J. Ennis \& Thomas R. Litwack, Psychiatry and the Presumption of Expertise: Flipping Coins in the Courtroom, 62 CAL. L. REV. 693 (1974); Abraham S. Goldstein \& Edith W. Fine, The Indigent Accused, The Psychiatrist, and the Insanity Defense, 110 U. PA. L. REV. 1061 (1962); Ralph Reisner \& Herbert Semmel, Abolishing the Insanity Defense: A Look at the Proposed Federal Criminal Code Reform Act in Light of the Swedish Experience, 62 CAL. L. REV. 753 (1974). 
and to the prosecution, ${ }^{227}$ a better reading of $A k e$ is that found in United States v. Sloan. 228

In Sloan, the Tenth Circuit reversed the lower court's denial of the defendant's request for an expert psychiatrist. The court relied on $A k e^{229}$ and the Criminal Justice Act, ${ }^{230}$ which together mandate the appointment of an expert as a "clear duty upon request"231 when mental condition is a significant factor at trial. Writing for the court, Judge Moore concluded that the clear duty to appoint an expert

cannot be satisfied with the appointment of an expert who ultimately testifies contrary to the defense on the issue of competence. The essential benefit of having an expert in the first place is denied the defendant when the services of the doctor must be shared with the prosecution. ${ }^{232}$

Considerable dispute rages over the defendant's right to an independent expert who could aid in the preparation and presentation of the defense..$^{233}$ Although the liberal reading of $A k e$ in Sloan is arguably the best, ${ }^{234}$ many courts construe the right to an expert to aid the defense much more narrowly. ${ }^{235}$ Many lower courts ${ }^{236}$ tend to focus on $A k e$ 's language refusing to

227. See, e.g., Granviel v. Lynaugh, 881 F.2d 185 (5th Cir. 1989), cert. denied, 495 U.S. 963 (1990).

228. 776 F.2d 926 (10th Cir. 1985). In Sloan, the defendant kidnapped a woman in Oklahoma City and forced her to accompany him to Hattiesburg, Mississippi. The defense requested that a psychiatrist be appointed and cited the defendant's history of psychiatric treatment. Id. at 927 . The government also filed a motion for psychiatric examination, which was granted. Defendant's renewed request for a psychiatric exam was denied for lack of justification. The court held that any bias could be corrected through cross-examination. Id. After the defendant's third request for assistance was denied, the defendant was convicted and sentenced to 75 years in prison. Id.

229. Judge Moore noted that Ake was decided after Sloan was tried. Nevertheless, the court's ruling relied heavily on the rationale of $A k e$. Id. at 928.

230. 18 U.S.C. \& $3006 \mathrm{~A}(\mathrm{e})(1988) ;$ see also infra part V.A.1.

231. Sloan, 776 F.2d at 929.

232. Id.

233. Ake v. Oklahoma, 470 U.S. 68,83 (1985).

234. Other cases have relied on Sloan in an effort not to "place a temporal limit on relevant proof of mental illness." United States v. Austin, 933 F.2d 833, 842 (10th Cir. 1991), cert. denied, 113 S. Ct. 1859 (1993). In Austin, the defendant was charged with resisting three correctional officers at Leavenworth Penitentiary, Leavenworth, Kansas. Id. at 834. The trial court denied the request for appointment of a psychiatrist for the defense on the grounds that the defendant, a paranoid schizophrenic who became entangled with a guard when his cell door opened, was not motivated in the incident by mental illness. Id. at 835 . The defendant was given an additional 18 months on his sentence. Id. The Tenth Circuit reversed, finding that under Ake, the request should have been granted and that the defendant was prejudiced when medical reports dealing with his prior state hospitalizations were excluded from evidence. Id. at 841-42. Austin also notes the breakdown that occurs any time an expert ultimately testifies contrary to the defense. Id. at 841 (citing Sloan, 776 F.2d at 929).

235. The term "defense consultant" within the context of Ake rights was coined by Justice Rehnquist in his dissent in Ake. He said that "the entitlement is to an independent psychiatric evaluation, not a defense consultant." Ake, 470 U.S. at 87 (Rehnquist, J., dissenting).

236. See, e.g., Silagy v. Peters, 905 F.2d 986, 1013 n.22 (7th Cir. 1990), cert. denied, 498 U.S. 1110 (1991). In Silagy, the Seventh Circuit noted that indigent defendants have no constitutional right to select a psychiatrist of their personal liking or to an expert that would testify exclusively in their favor. In Henderson v. Dugger, 925 F.2d 1309 (11th Cir. 1991), cert. denied, 113 S. Ct. 621 (1992), the defendant implicated himself in two murders and was sentenced to death. Id. at 1311. The court denied the defendant's claim that he had received ineffective assistance simply because the testimony had not been sufficiently favorable. Id. at 1316. In Martin v. Wainwright, 770 F.2d 918 (11th Cir. 1985), cert. denied, 479 U.S. 909, 922 (1986), the defendant was convicted by a state court of murder, 
recognize that a defendant has a right to an expert of the defendant's own choosing. ${ }^{237}$

Courts are particularly inclined to deny the appointment of an independent expert when the request is not timely. ${ }^{238}$ In State $v$. Harris, the defendant sought appointment of an independent handwriting expert immediately before trial. ${ }^{239}$ The court did not deny that the expert could have provided valuable assistance to the defendant but upheld the denial on the grounds that the defendant knew three months before trial that the state was seeking an expert, and neither the state nor the court ever led the defendant to believe the expert would not testify. In United States $v$. Williams, ${ }^{240}$ the court determined that any right to appointment of an independent psychiatric expert was waived when counsel at a preliminary hearing denied that the defendant would rely on a defense of insanity. ${ }^{241}$

\section{The Role of the Expert: A Defense Advocate}

The confusion and inconsistency in the lower federal and state courts ${ }^{242}$ appears to be unwarranted. The language in Ake defines the expert's role unequivocally as one of assistance in "evaluation, preparation, and presentation of the defense." 243 As one post-Ake court noted:

The right to psychiatric assistance does not mean the right to place the report of a "neutral" psychiatrist before the court; rather it means the right to use the services of a psychiatrist in whatever capacity defense counsel deems appropriate-including to

kidnapping, armed robbery, and forcible sexual battery and was sentenced to death. The defendant had been examined by mental health experts including four psychiatrists who were either court-appointed or recruited by the defense. The defendant's request for a neuropsychologist who would testify on organic brain damage was denied. Id. at 933 . On appeal, the Eleventh Circuit affirmed and held that $A k e$ provided "no solace" and that under $A k e$ the defendant was only entitled to an independent expert and not to favorable testimony. Id. at 934-35.

237. After providing that "the State must, at a minimum, assure the defendant access to a competent psychiatrist," the Court qualified this statement by writing "not to say, of course, that the indigent defendant has a constitutional right to choose a psychiatrist of his personal liking or to receive funds to hire his own." Ake, 470 U.S. at 83 . Intrinsically, this would put the defendant at more of a disadvantage than a monied counterpart.

238. See State v. Evans, 838 S.W.2d 185 (Tenn. 1992), cert. denied, 114 S. Ct. 740 (1994).

239. 839 S.W.2d 54 (Tenn. 1992), cert. denied, 113 S. Ct. 1368 (1993). The defendant, alleging failure to provide the expert violated due process, equal protection, and right to effective assistance of counsel, relied on the protections provided in $A k e$.

240. 998 F.2d 258 (5th Cir. 1993), cert. denied, 114 S. Ct. 940 (1994).

241. Id. at 263. Curiously the court noted that even if the request was not waived, there would have been no denial of due process because the court concluded that sanity would not have been a significant factor at trial. Id. at 264.

242. Part of the post-Ake confusion over the role of the expert is related to varied interpretations of the $A k e$ standard, particularly at the state court level. Some courts interpret $A k e$ to hold that a psychiatrist must be appointed at state expense any time the "mental condition of the defendant is likely to be an issue in the case." State v. Rhoades, 822 P.2d 960, 967 (Idaho 1991), cert. denied, 113 S. Ct. 962 (1993). This application goes beyond the Ake mandate of "insanity" as a "significant factor." Other state courts, however, more strenuously resist granting requests for state paid experts and focus on the notion that a "defendant's mental condition is not necessarily at issue in every criminal proceeding." Mills v. State, 603 So. 2d 482, 485 (Fla. 1992) (citing $A k e, 470$ U.S. at 82).

243. Ake, 470 U.S. at 83. 
decide, with the psychiatrist's assistance, not to present to the court particular claims of mental impairment. ${ }^{244}$

As a result, a fair reading of $A k e$ entitles defense counsel to either use or not use the expert as he deems appropriate in a number of capacities. The defense counsel's ability to use the psychiatrist (or arguably some other expert) should extend to excluding the expert's testimony if such a course of action would aid in the defense. ${ }^{245}$ Claims of ineffective assistance of counsel have not survived court challenge on the grounds that counsel excluded expert testimony ${ }^{246}$ or that an independent psychiatrist appointed for the defense was not given every record of the defendant's health. ${ }^{247}$

A difficult task for post-Ake courts has been to highlight the importance of a psychiatrist for the indigent defendant faithfully while still balancing the constraints imposed by $A k e^{248}$ In Harris $v$. Vasquez, ${ }^{249}$ the court provided a model of successful balancing. Harris was charged with two counts of murder, convicted, and sentenced to death. At the guilt phase of the trial, "[t]he State provided Harris with access to any competent psychiatrist of his choice."250 The Ninth Circuit held that the state "went beyond the requirements of $A k e$ " by allowing the defendant access to a psychiatrist that was not limited "in any way."251 The state even provided funds to Harris so that he could hire his own psychiatrist. On appeal, Harris alleged that his $A k e$ right to a competent exam and a competent state-funded psychiatrist had been denied. The Ninth

244. Smith v. McCormick, 914 F.2d 1153, 1157 (9th Cir. 1990) (emphasis added).

245. Id. The court notes that a disservice may be done to the defendant if the defense counsel is made an involuntary witness after consultation with the defense psychiatrist. Disclosures made to both the attorney and the attorney's expert should be unavailable. The attorney "must be free to make an informed judgment with respect to the best course for the defense." Id. at 1160 .

246. Mak v. Blodgett, 970 F.2d 614, 619 (9th Cir. 1992), cert. denied, 113 S. Ct. 1363 (1993) (holding that the failure to present psychiatrists to rebut damaging testimony was competent assistance because it kept the door closed to differing opinions and contributed to the defense effort). State courts have also grappled with ineffective assistance of counsel claims as they define the role of the expert. See, e.g., Engberg v. Meyer, 820 P.2d 70 (Wyo. 1991). In Engberg, Chief Justice Urbigkit in a separate opinion cited $A k e$ and then commented that the presentation of hypnosis evidence by an expert may have sixth amendment implications. Id. at 149 (Urbigkit, C.J., concurring in part and dissenting in part).

247. Shaw v. Delo, 971 F.2d 181 (8th Cir. 1992), cert. denied, 113 S. Ct. 1301 (1993).

248. See, e.g., State v. Garcia, 791 P.2d 244, 249-50 (Wash. Ct. App. 1990). Unfortunately, although $A k e$ acknowledged the "extraordinarily enhanced role of psychiatry in criminal law today," Ake, 470 U.S. 68, 85 (1985), many courts still seem to loosely perform this role themselves. In Garcia, the court said that the defendant's behavior had several probable causes including anger, depression, and withdrawal from drugs. Garcia, 791 P.2d at 250. As a result, the court of appeals affirmed the trial court's denial of a psychiatric expert. Id. Another example of the conclusory psychological judgments of courts is found in United States v. Williams, 998 F.2d 258 (5th Cir. 1993), cert. denied, 114 S. Ct. 940 (1994). In Williams, the court reasoned that since the defendant had handled a custody dispute involving his son pro se, there was no reason to believe that sanity would be a factor in the kidnapping charge which warranted appointment of a psychiatric expert under either the CJA or the Insanity Defense Reform Act. Id. at 266, 267 (citing United States v. Alden, 767 F.2d 314, 315 (7th Cir. 1984)).

249. 949 F.2d 1497 (9th Cir. 1990), cert. denied, 112 S. Ct. 1275 (1992). The defendant, along with his brother, stole an automobile for use as a bank robbery getaway car. At point blank range, Harris shot the two teenage boys who had been eating hamburgers in the car. Id. The trial court would eventually sentence Harris to death. Id. at 1500 .

250. Id. at 1516.

251. Id. 
Circuit affirmed the state trial court's denial of the request for review of the competence of Harris's psychiatric assistance. ${ }^{252}$ The Ninth Circuit acknowledged the critical nature of $A k e$ rights, ${ }^{253}$ but, as to the defendant's elevenyear-old case, it held that "such battles of psychiatric opinions during successive collateral challenges to a death sentence would place federal courts in a psycho legal quagmire."254

For an expert to function effectively as a member of the defense team, conditions should not be placed on the expert's role or services. In State v. White ${ }^{255}$ the court conditioned the appointment of experts on the preparation of written reports regarding the expert's evaluations. The reports, which were to be provided to the prosecution, were to contain all information related to the expert evaluations, including but not limited to raw scores, observations, conclusions, and any other pertinent information. The North Carolina Supreme Court held that the trial court exceeded its authority by so conditioning the reports. $^{256}$

\section{The Role of the Expert: An Aid to Judge, Jury, Counsel, and Defendant}

The assistance of psychiatrists and other experts in a criminal case is of critical importance. ${ }^{257}$ The Ake decision quantified the importance of the expert as a constitutional right, ${ }^{258}$ but also broadened the scope of the expert's role. ${ }^{259}$ This is particularly but not exclusively true of psychiatric experts. ${ }^{260}$ $A k e$ 's descriptions of the role of a psychiatrist in relation to the trier of fact, ${ }^{261}$

252. Id. at $1528-29$.

253. Id. at 1518-21. The court confronted the retroactivity implications with regard to an Ake claim in Harris's case. Under Teague v. Lane, 489 U.S. 288 (1989), exceptions can be made for "watershed rules of criminal procedure," which implicate fundamental fairness. Harris, 949 F.2d at 1519. After a lengthy analysis of Teague, the court concluded that Harris made no such claim, but rather offered "only declarations of experts who, eleven years after trial" would testify to Harris's receipt of incompetent assistance. Id. at 1521. Again, the court was particularly concerned that Ake violations would be distinguished from psychiatric malpractice questions.

254. Harris, 949 F.2d at 1518 . The Court rejected Harris's proposal of a new constitutional rule that would provide "[p]sychiatric medical malpractice review." Id.

255. 419 S.E.2d 557 (N.C. 1992).

256. A North Carolina statute provides that results or reports of a mental exam or test are not discoverable by the state if the defendant intends neither to introduce the reports or the results thereof into evidence at trial nor to call the witness who prepared the items to testify related to matters of the exam. N.C. GEN. STAT. § 15A-905(b) (1988).

257. People v. Lanari, 811 P.2d 399, 402 (Colo. App. 1989) (dissenting opinion) ("An expert witness' analysis of evidence is often as critical to a case as the evidence itself."), aff'd in part, rev'd in part, 827 P.2d 495 (Colo. 1992).

258. "[T]he assistance of a psychiatrist may well be crucial to the defendant's ability to marshal his defense." Id. at 402 (quoting Ake v. Oklahoma, 470 U.S. 68,80 (1985)).

259. One state court noted that $A k e$ discussed the inexact nature of psychiatry and even argued that $A k e$ could be read in part to entitle the prosecution to a compulsory psychiatric exam by its own expert to rebut the defendant's defense theories. State v. Hess, 828 P.2d 382 (Mont. 1992).

260. See supra part II.C, III.A.

261. Ake, 470 U.S. at 80 ("In this role, psychiatrists gather facts ... that they will share with the judge or jury; they analyze the information ... and ... draw plausible conclusions about the defendant's mental condition, and . . any disorder . . . ; and they offer opinions about . . behavior at the time in question."); id. ("[P]sychiatrists can translate a medical diagnosis into language that will 
counsel, ${ }^{262}$ prosecution, ${ }^{263}$ and the court could, as noted, apply equally to nonpsychiatric experts. ${ }^{264}$ Since Ake, courts have grappled with trying uniformly to determine the situations in which experts should be appointed. ${ }^{265}$ This confusion over the meaning and reach of $A k e$ has constricted access for the indigent as a class to both psychiatric experts and nonpsychiatric experts. ${ }^{266}$

Without the benefit of the Criminal Justice Act, state courts have had particular difficulty integrating the Ake standard with the broader view that the role of the expert is increasingly important. In Scott $v$. Indiana ${ }^{267}$ the Indiana Supreme Court noted that "in attempting to decide what is necessary, a trial court should determine whether the proposed services would bear on an issue which is generally regarded to be within the common experience of the average person, or on one for which expert opinion would be necessary." 268 The Scott court noted the Ake mandate of providing the indigent with the tools to present a claim fairly within the adversary system, but simply affirmed the denial on the grounds that " $[t]$ he jury could decide without an expert's testimony whether Scott was too intoxicated ...."269 Scott reflects the view of most state courts

assist the trier of fact, and therefore offer evidence in a form that has meaning."); id. at 82 ("With such assistance, the defendant is fairly able to present at least enough information to the jury, in a meaningful manner, as to permit it to make a sensible determination.").

262. Id. at 83 ("assist in evaluation, preparation, and presentation of the defense"). One of the most important aids is to "assist in preparing the cross examination" of state witnesses. Id. at 82 . See infra part III.E. Experts can also identify "issues relevant to the defense ... [in order to] determine whether the insanity defense is viable." Ake, 470 U.S. at 82.

263. Ake, 470 U.S. at 80 ("They know the probative questions to ask of the opposing party's psychiatrists and how to interpret their answers.").

264. E.g., Little v. Armontrout, 835 F.2d 1240, 1244 (8th Cir. 1987), cert. denied, 487 U.S. 1210 (1988) (holding that the hypnosis expert could have presented the limitations of hypnosis and explained memory theory to the better understanding of the court and jury).

265. See, e.g., People v. Knuckles, 589 N.E.2d 1080, 1082-83 (IIl. Dist. Ct. App. 1992), rev'd, 1994 WL 46880 (Ill. Feb. 17, 1994). After a lengthy recitation of the salient points of Ake, the court observed that the indigent defendant needed the expert to assess the wisdom of asserting an insanity defense and to help counsel intelligently scrutinize adverse testimony. Id. at 1083.

266. There are comparatively few instances of grants for nonpsychiatric assistance. Most courts reason that $A k e$ "cannot be broadly interpreted to require a state to provide experts of any category of a defendant's own choosing or to assist him in whatever defenses he chooses." Siebert v. State, 562 So. 2d 586, 590 (Ala. Crim. App. 1989), affd sub nom., Ex parte Siebert, 562 So.2d 600 (Ala.), cert. denied, 498 U.S. 963 (1990) (quoting Ex parte Grayson, 479 So. 2d 77, 82 (Ala. Crim. App. 1984), cert. denied, 474 U.S. 865 (1985)). The polling expert in Siebert was denied. Id. at 588-90; see also United States v. Valverde, 846 F.2d 513 (8th Cir. 1988) (denying request for a linguistic expert).

267. 593 N.E.2d 198 (Ind. 1992). The defendant was convicted of numerous charges in connection with forced sexual conduct of a young girl and sentenced to 110 years. Id. at 199. He was denied an expert on the issue of intent after arguing that he was so intoxicated he could not form the requisite intent. Physicians and psychiatrists were appointed to assist the defendant. Id.

268. Id. at 200 (citation omitted).

269. Id. at 202. The court's analysis attempted to balance the purpose of the request, the timeliness of the request, the ability of counsel to perform the purpose for which the expert is requested and other factors. Id. at 199-202. The court's ultimate decision to affirm, however, was based largely on the fact that the government did not intend to have an expert analogous to the one requested by the defendant, and as a result the defendant's request was ipso facto unnecessary. Id. at 202. 
that experts have no exploratory role, though arguably exploration would be one of the expert's most useful functions. ${ }^{270}$

The courts that grant indigent defendants funding for an expert to assuage the inequities faced by the indigent exhibit a better reading of Ake than the courts that focus on a rigid "significant factor at trial" test. ${ }^{271}$ Courts should err on the side of delivering the expert as a "basic tool" to a defense, which a defendant may not be able to prove without the assistance of an expert in the first place. ${ }^{272}$ Both federal and state courts have had difficulty capturing the importance of the tripartite role of the "independent" expert to the defendant, the jury, and counsel. ${ }^{273}$ Many state courts imply that the expert requested may have provided useful defense assistance and then proceed to deny the request for services. For example, in Kansas $v$. Wainwright, ${ }^{274}$ the defendant sought, prior to trial, the use of an expert on bloodhound evidence. The court noted that "[b]loodhound evidence is indeed unique and novel, and clearly, a bloodhound expert might well have helped" the defendant. ${ }^{275}$ The defendant, however, did not show that the expert's services were necessary in order to prepare for trial. ${ }^{276}$

In State v. Stow, ${ }^{27}$ the defendant sought an expert in eyewitness identification after being accused of kidnapping. The trial court held that the request for an expert was not reasonable because the relevance and the admissibility of expert testimony were in question, and the request was not for a psychologist who had dealt with the victim and could testify that the victim had memory problems. The court also noted that the psychologist would invade the province

270. The Scott court noted that an expert need not be appointed when the purpose of the expert appears to be exploratory only, when the services will go toward an ancillary question rather than a substantial one, or where the attorney could provide the services. Id; see also Hough v. State, 560 N.E.2d 511 (Ind. 1990).

271. See, e.g., State v. Harris, 789 P.2d 60, 68 (Wash. 1990) (en banc) (applying "significant factor at trial" standard).

272. Dunn v. Roberts, 963 F.2d 308 (10th Cir. 1992), is a good example of a court reading Ake to warrant the appointment of an expert because it will simply help the defense to present its case and help the jury to understand. In a Kansas state trial court, the defendant was convicted of aiding and abetting a kidnapping and felony murder. Id. at 309-10. The trial court denied the grant of an expert to explain the effects of battered woman's syndrome. Id. at $310-11$. On appeal the Tenth Circuit affirmed a district court's grant of habeas corpus relief. The defendant was granted a new trial with the assistance of an expert in the preparation and preservation of her defense. Id. at 314. The court held that the defendant should not be denied funds to present relevant information bearing on the crime of which she was convicted. Id.

273. First, the expert can aid a defendant in determining whether a defense based on mental condition is warranted. Second, the expert can coherently present to the jury his or her observations of the defendant. Third, the expert can assist in preparing cross-examination of government experts. See United States v. Fazzini, 871 F.2d 635, 637 (7th Cir.) (citation omitted), cert. denied, 493 U.S. 982 (1989).

274. 856 P.2d 163 (Kan. App. 1993).

275. Id at 167 . This case is also illustrative of the consistency with which courts deny requests for services which, in the view of the court, are not timely made, a constraint which does not apply to a paying defendant. Here the decision not to grant the request for services was made, in part, because the defense did not request the expert until several days before trial. Id.

276. Id.

277. 620 A.2d 1023 (N.H. 1993). 
of the jury ${ }^{278}$ and that state funds were in short supply. ${ }^{279}$ Unfortunately, many such decisions reflect a willingness by the court to infringe on the important need of the defense to use an expert in whatever way the defense chooses.

In Mendoza v. Leapley, ${ }^{280}$ the defendant sought appointment of a psychologist to prepare a defense to the charge of first-degree rape. The lower court denied the request, and defendant was convicted. On appeal, the Eighth Circuit held that the defendant was convicted based on the state's physical evidence and the victim's testimony. The court reasoned that since the State did not present psychological evidence, the defendant did not require an expert to respond to the evidence presented. ${ }^{281}$ The Mendoza court's rationale, therefore, arguably deprived the defendant of a more complete defense.

\section{E. The Expert and Cross-Examination}

The fact that state and lower federal courts have seemingly missed the Ake court's reference to the value of experts in the preparation of cross-examination is an example of the difficulty these courts have had in correctly reading $A k e e^{282}$ Although Ake expressly notes the importance of an expert in preparing cross-examination, far too many courts have focused instead on the defense counsel's cross-examination of the prosecution's expert witness as a substitute for the defense receiving the use of its own expert. ${ }^{283}$ Few courts seem to read $A k e$ generously in the area of providing psychiatric experts to help prepare for cross-examination. ${ }^{284}$

Reliance on cross-examination also produces the courts' denial of experts in many nonpsychiatric cases. ${ }^{285}$ In Jackson $v$. Yist ${ }^{286}$ the trial court's denial

278. Federal courts also routinely deny appointment of experts where the subject matter is within the ken of the average juror. See United States v. Larkin, 978 F.2d 964 (7th Cir. 1992) (upholding denial of expert witness on hazards of eyewitness identification), cert. denied, $113 \mathrm{~S}$. Ct. 1323 (1993).

279. The Supreme Court of New Hampshire upheld the denial of services but noted that lack of funds standing alone was an insufficient grounds for denial. Stow, 620 A.2d at 1027.

280. 5 F.3d 341 (8th Cir. 1993).

281. Id at 342 . The court reasoned that an expert need only be provided "if the defendant shows 'a reasonable probability that an expert would aid in his defense, and that denial of expert assistance would result in an unfair trial."' Id. (quoting Little v. Armontrout, 835 F.2d at 1244).

282. The $A k e$ Court noted that the widespread reliance on psychiatry by both the state and those who could afford a psychiatric expert "leads to the inexorable conclusion that" a psychiatrist was crucial in preparing the cross-examination of the state's psychiatric witness. Ake v. Oklahoma, 470 U.S. at 82.

283. See, e.g., Magwood v. Smith, 791 F.2d 1438 (11th Cir. 1986). In Magwood the state presented six experts. The defendant's request for an independent psychiatrist was denied. Id. at 1443. Preparation of cross-examination in such situations is obviously difficult. See also Kansas v. Wainwright, 856 P.2d 163 (Kan. App. 1993) (holding that all of the defense questions could be answered through cross-examination).

284. One of the cases that provides a psychiatrist for the preparation of cross-examination based on the mandate of Ake is United States v. Crews, 781 F.2d 826 (10th Cir. 1986). Even though four treating or court-appointed psychiatrists testified, the Tenth Circuit nonetheless held that the defendant was entitled to a psychiatrist to aid in the preparation of cross-examination. Id. at 833-34.

285. See, e.g., Banks v. State, 810 P.2d 1286 (Okla. Crim. App. 1991), cert. denied, 112 S. Ct. 883 (1992). The defendant alleged that a fingerprint expert could have discredited a prosecution witness. The court affirmed a denial of the request for the fingerprint expert on the grounds that a thorough 
of an eyewitness identification expert was affirmed because the court of appeals held that cross-examination was sufficient "to alert jurors to specific conditions that render a particular eyewitness identification unreliable."287 In Williamson $v$. State, ${ }^{288}$ the court argued that scientific evidence is "not vulnerable to inaccurate resolution" and "does not ordinarily call for a defense expert." 289 In Williamson, defense counsel cross-examined the state witnesses, and the court held that due process was not violated when a request for an expert was denied. ${ }^{290}$

Moore v. Kemp $p^{291}$ illustrates some of the problems that attorneys representing indigents face in securing experts. In Moore, the defendant alleged that without appointed experts who could serve as defense consultants, proper crossexamination of the state's microanalyst and serologist as to the tests they performed could not be conducted. ${ }^{292}$ The court admitted that "defense counsel may be unfamiliar with the specific scientific theories implicated in a case" and obligated the defense counsel to "inform" himself or herself about those scientific theories. ${ }^{293}$ Courts often require an explanation of considerable depth ${ }^{294}$ as to how the requested expert will help before the request is granted. However, the very purpose for which the expert may be needed by defense counsel is to "inform" counsel so that they can explain to the court why the expert is necessary to the particular defense contemplated. In this manner, the expert may aid counsel in rebutting the scientific theories in a case such as Kemp.

\footnotetext{
cross-examination had been conducted. Id. at 1293.

286. 921 F.2d 882 (9th Cir. 1990).

287. Id. at 886 (citing United States v. Cristophe, 833 F.2d 1296, 1300 (9th Cir. 1987)); see also United States v. Brewer, 783 F.2d 841 (9th Cir.), cert. denied, 479 U.S. 831 (1986).

288. 812 P.2d 384 (Okla. Crim. App. 1991), cert. denied, 112 S. Ct. 1529 (1992).

289. Id. at 396 (citing Plunkett v. State, 719 P.2d 834 (Okla. Crim. App.), cert. denied, 479 U.S. 1019 (1986)).

290. 812 P.2d at 396.

291. 809 F.2d 702 (11th Cir.), cert. denied, 481 U.S. 1054 (1987).

292. Id. at 709 .

293. Id. at 712; see also United States v. Gadison, 8 F.3d 186, 191 (5th Cir. 1993) (affirming trial court's denial of a government-funded investigator, in part because "no showing was made that defense counsel had ferreted out information through his own effort which was likely to lead to the discovery of relevant evidence").

294. State courts also impose arguably heavy investigative duties on counsel who are requesting experts. See, e.g., State v. Biegenwald, 594 A.2d 172 (N.J. 1991). There, the request for a psychiatric expert in a subsequent proceeding was denied because counsel did not adequately attempt to uncover new evidence with regard to the defendant's condition at the time the crime was committed. Id. at 204 (Handler, J., concurring). A distinction should be made between imposing investigative duties on counsel and merely making a reasonable showing of need.
} 


\section{$\mathrm{V}$ \\ LEgISLATION PROVIDING EXPERT SERVICES FOR THE POOR}

\section{A. The Criminal Justice Act of 1964}

1. Why the Statute was Enacted. Legislation is one way of redressing what has been called "the imbalance in the criminal process when the resources of the United States Government are pitted against an indigent defendant."205 In response to the need to provide those financially disadvantaged with attorneys and the expert services crucial to an adequate defense, Congress enacted the Criminal Justice Act of 1964 (the "CJA"). ${ }^{296}$ The CJA provides compensation to court-appointed counsel, reimbursement for out-of-pocket expenses, and payment for other defense services for persons charged with federal crimes (other than petty offenses) who are "financially unable to obtain ... adequate representation." 297

The services of both psychiatric and nonpsychiatric experts were clearly intended to be part of the basic defense tools provided by the CJA. With reference to the CJA, former President John F. Kennedy wrote:

In the typical criminal case the resources of government are pitted against those of the individual. To guarantee a fair trial under such circumstances requires that each accused person have ample opportunity to gather evidence and to prepare and present his cause. Whenever the lack of money prevents a defendant from securing an experienced lawyer, trained investigator or technical expert, an unjust conviction may follow. ${ }^{298}$

The importance of experts was so great even twenty years before the Ake decision $^{299}$ that the CJA provided for experts even when defendants had retained counsel but were too poor to pay for the accompanying expert

295. United States v. Durant, 545 F.2d 823, 827 (2nd Cir. 1976); see also United States v. Austin, 933 F.2d 833, 841 (10th Cir. 1991) ("when a state brings its judicial power to bear . . . it must take steps to assure that the defendant has a fair opportunity to present his defense" (quoting Ake v. Oklahoma, 470 U.S. at 76)).

296. Now the Criminal Justice Act Revision of 1988. 18 U.S.C. § 3006A (1988 \& Supp. IV 1992). The CJA was originally enacted as the Criminal Justice Act of 1964, 78 Stat. 552 (codified as amended at 18 U.S.C. $\$ 3006 \mathrm{~A})$.

297. 18 U.S.C. $\S 3006 \mathrm{~A}(\mathrm{e})(1)$. The CJA is significant for, among other reasons, it expands the eligibility for benefits. In order to qualify for representation and defense (expert) services, the defendant need not be completely destitute. See S. REP. No. 346, 88th Cong., 1st. Sess. 13 (1963) (report of the Judiciary Conference of the United States); H.R. DOC. No. 62, 89th Cong., 1st Sess. 6 (1965).

298. Letter from President John F. Kennedy to Hon. John W. McCormick, Speaker of the House of Representatives (March 8, 1963), reprinted in 1964 U.S.C.C.A.N. 2993.

299. See Proffitt v. United States, 582 F.2d 854, 857 (4th Cir. 1978) (quoting Senator Hruska's testimony in support of the 1964 proposed legislation: "An adequate representation commonly entails more than the mere presence of a lawyer in court. To prepare his defense, [a defendant] may need investigative, expert, or other services." 110 CONG. REC. 18521 (1964)). 
services. $^{300}$ Persons who are eligible for representation under the CJA but who elect to proceed pro se may, upon request, receive court authorization to obtain investigative, expert, and other services under subsection (e) of the CJA. $^{301}$ Benefits under the CJA are administered under "Criminal Justice Act Plans" promulgated by each United States district court. Procedures are prescribed primarily by the Defender Services Division of the Administrative Office of the United States Courts with and under the direction of the Judicial Conference Committee on Defender Services. ${ }^{302}$ Administration of the CJA is driven by the Guidelines for the Administration of the Criminal Justice Act ("CJA Guidelines"), which have been enacted with the approval of the Judicial Conference of the United States. ${ }^{303}$ This section will examine the CJA and its subsequent interpretation by the courts, and will also consider the CJA in relation to cases such as $A k e$, noting the heavy reliance by the lower courts on both the CJA and the Ake standard in distributing expert services.

2. The Statute. The CJA provides in part: "Counsel for a person who is financially unable to obtain investigative, expert, or other services necessary for adequate representation may request them in an ex parte application. Upon finding ... that the services are necessary ... the court ... shall authorize counsel to obtain the services." ${ }^{304}$ The CJA specifies that expert services shall be requested in an ex parte proceeding, at which defense counsel must make a preliminary showing of need. In United States v. Goodwin, ${ }^{305}$ the trial court refused to hold an ex parte proceeding before denying the request for expert services. The trial court denied the request on the ground that the defense alleged no facts of which the defendant was not aware and which would require investigation. Although the Seventh Circuit affirmed the conviction on appeal, ${ }^{306}$ it indicated that, if defense counsel asserts that expert services are necessary for an adequate defense, the district courts should not rule on the application for expert services without first conducting an ex parte proceeding. ${ }^{307}$ Courts have also held that conducting a pretrial hearing on defendant's

300. The House Report stated:

As the bill passed the Senate, services other than counsel-such as fingerprint, psychiatric, ballistic, investigator, etc.- would be available to all defendants who could not afford them, regardless of whether they were represented by appointed or by retained counsel. The language of the House version would seem to make such services available only to defendants represented by appointed counsel, despite the fact that in the House debate it was made clear this restriction was not intended. The conferees have therefore made the House and Senate intention explicit.

H.R. REP. NO. 1709, 88th Cong., 2d Sess. 6 (1964).

301. See 7 GUIDE TO JUDICIARY POLICIES AND PROCEDURES, Appointment of Counsel in Criminal

Cases $\$ 3.01 \mathrm{~B}$ (1990 as amended) [hereinafter CJA GUIDELINES].

302. This committee was formerly called the Committee to Implement the Criminal Justice Act.

303. See CJA GUIDELINES, supra note 301.

304. 18 U.S.C. \& 3006A(e)(1) (1988 \& Supp. IV 1992) (emphasis added).

305. 770 F.2d 631 (7th Cir. 1985), cert. denied, 474 U.S. 1084 (1986).

306. Id. at 635 .

307. Id at 634 . 
motion for expert services with government counsel present, rather than ex parte, is error. ${ }^{308}$

In $A k e$, the Court cited the CJA and noted that "Congress has provided that indigent defendants shall receive the assistance of all experts necessary for an adequate defense." 309 The Ake Court acknowledged that the CJA provides for both psychiatric and nonpsychiatric experts. Lower federal courts have unfortunately varied widely in their application of the CJA both before and after Ake. The CJA is a mechanism for funding and does not necessarily provide plenary power for the federal courts when considering appointment of experts. In Jackson $v$. Vasquez, ${ }^{310}$ the indigent prisoner filed a request for an order compelling the warden to transport him to a hospital for a brain scan and psychological analysis. The court held that the defendant is merely entitled to funds to allow the "defendant's attorneys to obtain investigative, expert or other services on behalf of the defendant" and "does not empower the district court to compel action from a state official." 311

a. Psychiatric experts under the CJA. Before Ake, lower courts were resistant to requests for psychiatric experts under the CJA. ${ }^{312}$ In United States v. Alden, ${ }^{313}$ the defendant indicated an intention to raise an insanity defense. The trial court refused to appoint a psychiatrist under the CJA. On appeal, the Seventh Circuit affirmed on the ground that the only conceivable defense ${ }^{314}$ was that of insanity and that since this defense was not viable, the expert would not be required. ${ }^{315}$ The fact that a reasonable private attorney might have hired the expert was not sufficient. ${ }^{316}$

$A k e$, however, recognizes that the state has relied on psychiatrists as examiners, consultants, and witnesses, as have defendants who can afford to pay for experts. Nevertheless, leveling the playing field for the indigent defendant has been difficult for most post-Ake courts. A majority of courts have had difficulty in recognizing the importance of the independent expert and applying

308. See, e.g., United States v. Greschner, 802 F.2d 373, 379-80 (10th Cir. 1986), cert. denied, 480 U.S. 908 (1987).

309. Ake v. Oklahoma, 470 U.S. $68,79-80$ (1985).

310. 1 F.3d 885 (9th Cir. 1993).

311. Id. at 888 (emphasis in original). The court also noted that it would be appropriate to disburse the funds in ex parte proceedings so that the defense strategy would not be compromised by premature revelation to the prosecution.

312. See, e.g., United States v. Jackson, 587 F. Supp. 80, 80-81 (M.D. Tenn. 1983).

313. 767 F.2d 314 (7th Cir. 1984).

314. Id. at 318. The defendant was caught lying in the snow by the fence of the United States Penitentiary at Marion, Illinois as he tried to escape. Id. at 316. The defendant claimed that he was God. Id. at 317.

315. Id. at 317-20.

316. Id. at 318-19. The court said that the defendant must have a plausible defense and that it would not "subsidize" mere "fishing expeditions." Id. at 319. The disturbing part of the decision is that the court also recognized that subsection (e) relief should not be refused when the underlying facts reasonably suggest that further exploration may be beneficial to the defendant. Id. Without an expert, however, this may be impossible to determine. 
the Ake standard to the language in the CJA that calls for an expert's assistance.

Post-Ake opinions generally deny requests for psychiatric experts under the $\mathrm{CJA}^{317}$ In United States $v$. Fazzini, ${ }^{318}$ the court noted the important rights guaranteed by Ake and the CJA. While holding that the indigent defendant has a right to present any evidence relevant to a viable defense, the Eighth Circuit affirmed the district court's denial of an expert. ${ }^{319}$ Decisions such as Fazzini seem to recognize the importance of creating a more level playing field for the indigent through the grant of psychiatric experts, but have difficulty with the idea that the experts need to be independent. ${ }^{320}$ Many post- $A k e$ courts still rely on expertise coming from sources other than experts appointed for the defendant, such as the findings made by federal medical facilities ${ }^{321}$ or by neutral prosecution experts. ${ }^{322}$ But what seems to be clearly contemplated by the CJA and reinforced by $A k e$ is that the expert is to assist in the preparation and presentation of the defense. ${ }^{323}$

The decision to grant or deny a motion for services under the CJA is committed to the discretion of the trial court and will only be overturned where there is an abuse of that discretion. ${ }^{324}$ The vast majority of published opinions in this area are those denying motions for services under the CJA. Post-Ake courts, rather than erring on the side of providing the defendant with the requested services as basic tools, simply deny the claim if they believe the defendant does not have a plausible defense. ${ }^{325}$

One of the few lower federal court decisions that successfully rely on the CJA and provide insightful incorporation of $A k e$ 's definition of an indigent's right to experts is United States v. Crews. ${ }^{326}$ In Crews, the defendant was admitted to a Veterans Administration hospital and while there threatened to

317. See, e.g., United States v. Spotted War Bonnet, 882 F.2d 1360, 1362 (8th Cir. 1989), cert. denied and judgment vacated on other grounds, 497 U.S. 1021 (1990); United States v. Blade, 811 F.2d 461, 467 (8th Cir.), cert. denied, 484 U.S. 839 (1987).

318. 871 F.2d 635 (7th Cir.), cert. denied, 493 U.S. 982 (1989).

319. Id. at 637. The Eighth Circuit held that the district court should not have asked whether the defendant was likely to be able to prove he actually suffered from a mental condition but whether evidence of mental condition would have been a viable defense. Id. at 640 .

320. One of the post-Ake cases that recognizes the need for an independent psychiatrist under the Act is United States v. Vachon, 869 F.2d 653 (1st Cir. 1989). In a straightforward attempt to level the playing field, the trial court granted the defendant a psychiatric expert and denied a second expert since the government only relied on one expert of its own. Id. at 659.

321. See Fazzini, 871 F.2d at 640.

322. See, e.g., United States v. Rinchack, 820 F.2d 1557, 1564-65 nn.9-10 (11th Cir. 1987).

323. In United States v. Williams, 998 F.2d 258 (5th Cir. 1993), cert. denied, 114 S. Ct. 940 (1994), the court noted that experts fill an expanded role under the CJA. The Insanity Defense Reform Act of 1984,18 U.S.C. $\$ 4242$ (1988 \& Supp. IV 1992), authorized a mental exam on sanity at the time of the offense provided notice of intent to rely on insanity is given and the government also moves for the exam. Under the CJA, however, the mental health expert "fills a different role," and requests for experts should be granted if necessary for adequate protection.

324. Williams, 998 F.2d at 264.

325. Rinchack, 820 F.2d at 1564.

326. 781 F.2d 826 (10th Cir. 1986). 
kill former President Reagan. ${ }^{327}$ The lower court appeared to grant a psychiatrist, but since no psychiatrist was apparently available locally, the trial proceeded without expert assistance for the defense. ${ }^{328}$ On appeal, the Tenth Circuit reversed, stating that an $A k e$-mandated, government-funded psychiatrist for the defense was the right of an indigent defendant and that the CJA was essential to assist counsel for the defendant in preparing the defense. ${ }^{329}$

b. Nonpsychiatric experts under the CJA. In United States $v$. Durant, ${ }^{330}$ the defendant was convicted of bank robbery in the district court. Prior to trial, he sought appointment of a government-funded fingerprint expert, both for purposes of the defense case-in-chief and to help prepare for crossexamining the government's expert. ${ }^{331}$ On appeal, the defendant claimed the trial court erred in denying him the government-funded fingerprint expert. The Second Circuit reversed, stating that

the purpose of the Act, confirmed by its legislative history, is clearly to redress the imbalance in the criminal process when the resources of the United States Government are pitted against an indigent defendant. .. . This does not mean that application for expert assistance should be granted automatically. . . . But it does mean that the Act must not be emasculated by niggardly or inappropriate construction. ${ }^{332}$

In Durant, the Second Circuit noted that the phrase "necessary to an adequate defense" in 18 U.S.C. section 3006A(e) includes defense preparation for cross-examination of government witnesses. ${ }^{333}$

In determining whether a nonpsychiatric expert is too unusual or expensive to merit appointment, consideration should be given to whether the circumstances from which the need arose would usually result in an additional expense for a fee-paying client. ${ }^{334}$ Frivolous claims are to be rejected. ${ }^{335}$

Courts are most likely to grant expert services when the request relates to "pivotal" evidence. ${ }^{336}$ Often, however, the defendant needs the expert merely because it will help the defendant's case in some lesser but valid measure.

Investigators are one of the types of experts most commonly sought under the CJA. Often a court will refuse a nonpsychiatric expert if the court believes that no scientific basis for the theory to be advanced exists. ${ }^{337}$ Lower courts

327. Id. The defendant apparently made the threatening statements to a nurse the day after the television show "The Day After" was aired depicting the fictitious nuclear devastation of Lawrence, Kansas. Id. at 829 . The defendant was convicted and sentenced to four years imprisonment. Id.

328. Id.

329. Id. at 834 .

330. 545 F.2d 823 (2d Cir. 1976).

331. Id. at 826-27.

332. Id. at 827; accord United States v. Patterson, 724 F.2d 1128 (5th Cir. 1984).

333. Durant, 545 F.2d at 827.

334. See In the Matter of forma pauperis proceedings, 53 Comp. Gen. 638, 642 (1974).

335. See, e.g., In re Grand Jury Investigation, 791 F. Supp. 192 (S.D. Ohio 1992) (holding that request for expert to administer polygraph examination to strengthen relationship between defense counsel and the defendant was not a valid use of section 3006A(e)).

336. United States v. Sanchez, 912 F.2d 18, 22 (2d Cir. 1990).

337. See, e.g., United States v. Bercier, 848 F.2d 917, 919 (8th Cir. 1988). The defendant was charged with manslaughter while driving while intoxicated. Id. at 918 . Defendant disputed his identity as the 
are equally reticent to appoint psychiatric and nonpsychiatric experts under the CJA when cross-examination is perceived to be an adequate substitute. ${ }^{338}$ Other experts have been requested in numerous areas including interpreters ${ }^{339}$ and forensic chemists. ${ }^{340}$

Transcripts are made available to the indigent under subsection (e) of the $\mathrm{CJA}^{341}$ Courts have generally allowed the indigent to be provided with transcripts comparable to those which the government obtains for itself. ${ }^{342}$ This makes good sense. A defendant should not be put at a disadvantage because of poverty when the government is able to order and obtain a transcript of prior testimony ("daily transcript") in the same case. Likewise, transcripts of a previous trial that end in a hung jury or a declaration of a mistrial should be available on a showing of need based on section 3006A(e) and on Griffin and its progeny.

\section{The Effect of Statutory Case Compensation Maximums for Expert} Services. When appointed counsel has received prior authorization ${ }^{343}$ from the judge for investigative, expert, or other services, compensation for expert services under the CJA is limited to $\$ 1000 .^{344}$ In 1970 , the CJA was amended to provide for a waiver of the statutory compensation maximum for expert defense services. ${ }^{345}$ Payment in excess of the $\$ 1000$ limit may now be granted if a case is one of unusual duration or of a character that requires in fairness that extra compensation be awarded. ${ }^{346}$ With the cost of experts on the rise

driver and sought a hypnotist. Id at 919 . The request was denied pursuant to section $3006 \mathrm{~A}(\mathrm{e})$. Id . The Eighth Circuit affirmed the trial court's decision, which held that there was no showing that the hypnotist could enhance memory lost in an alcoholic blackout. Id.

338. See, e.g., United States v. Brewer, 783 F.2d 841, 843 (9th Cir.), cert. denied, 479 U.S. 831 (1986).

339. United States v. Desist, 384 F.2d 889 (2d Cir. 1967), aff'd, 394 U.S. 244 (1969).

340. United States v. Erb, 596 F.2d 412 (10th Cir.), cert. denied, 444 U.S. 848 (1979).

341. See CJA GUIDELINES, supra note 301, §3.12A(1) (1993 as amended). Transcripts may be obtained through the filing of an authorization and voucher for payment, which must be signed by the district judge. Attorneys who so elect may also obtain reimbursement for transcripts as an out-ofpocket expense. Regardless of which method for payment is used, the limitations of $\$ 1000$ and $\$ 300$ for expert services do not apply to the cost of transcripts. Id.

342. See United States v. Bari, 750 F.2d 1169, 1182 (2d Cir.), cert. denied, 472 U.S. 1019 (1984) (holding that the district court abused its discretion in refusing to grant the indigent defendant a daily transcript when the government had ordered the transcripts for itself); United States v. Scarpa, $691 \mathrm{~F}$. Supp. 635, 636 (E.D.N.Y. 1988) (holding that an indigent defendant can obtain daily transcripts where government receives the same).

343. Without prior authorization, counsel may seek expert services under the Act for his or her client provided that the cost of the services does not exceed $\$ 300$ plus reasonable expenses. See CJA GUIDELINES, supra note 301, § 3.02B.

344. See id. \$ 3.02A. There is no limit in federal capital cases and federal habeas corpus proceedings.

345. H.R. REP. No. 91-1546, 91st Cong., 2d Sess. (1970), reprinted in 1970 U.S.C.C.A.N. 3982, at 3991.

346. An example of the type of case in which the $\$ 1000$ maximum will not be waived is United States v. Gossett, 877 F.2d 901 (11th Cir. 1989), cert. denied, 493 U.S. 1082 (1990). In Gossett, the defendant was charged with murder and mutiny on the high seas and had been granted an independent investigator. Id. at 903 . The defendant sought investigative services in excess of the $\$ 1000$ limit to track a transient witness. The Eleventh Circuit affirmed the trial court's holding that the request was not reasonable and that it did not require a waiver of the type contemplated by the Act. Id. at 903-04. 
and the large number of hours that may be required of an appointed expert in preparation and presentation of the defense, the waiver provision is absolutely essential. Generally, trial courts tend to resist granting waivers and often make the determinations of fee awards and waivers of the maximum on an ad hoc basis. ${ }^{347}$

Defendants may also be required to repay expenses for expert services or counsel. In Hanson v. Passer, ${ }^{348}$ the defendant sought court-appointed counsel on a charge of selling alcohol to a minor and was ordered to pay $\$ 1000$ prior to the receipt of counsel. The Eighth Circuit held that a defendant may be required to repay expenses incurred in preparing a defense provided that indigents are forever exempt. ${ }^{349}$

When funds are allocated for expert services under the CJA, the services are "defense" services when the defendant selects the expert and controls the disclosure of the expert's report. If experts are used and payment is from another source, the court or the government selects the expert and persons other than the defendant have access to the expert's report.

\section{B. State Statutes Authorizing Defense Services}

A majority of states provide indigent defendants with the assistance of a psychiatrist in certain circumstances. ${ }^{350}$ States provide expert defense services to indigent defendants either by reimbursement or direct provision of funds, ${ }^{351}$ by court appointment of an expert, ${ }^{352}$ or by funding the state's public defender

347. See Martin v. Dugger, 708 F. Supp. 1265, 1267 (S.D. Fla. 1989). The court granted the three medical experts each $\$ 1000$ plus expenses, apparently on the grounds that each testified for less than one day. Although the services could not have been obtained without prior authorization, the court would not waive the statutory limit. Id.

348. 13 F.3d 275 (8th Cir.), cert. denied, 114 S. Ct. 1859 (1994).

349. Id.

350. Ake v. Oklahoma, 470 U.S. 68, 78-79 n.4 (1985) (listing forty states that make expert defense assistance available to indigent defendants).

351. See, e.g., ILL. CoMP. STAT. ch. $725 \S 5 / 113-3$ (Smith-Hurd 1993 \& Supp. 1994) (funding for expert defense assistance for capital cases only is not to exceed $\$ 250$ ); KY. REV. STAT. ANN $§ 31.070$ (Baldwin 1992) (fees plus expenses for defense is not to exceed \$1000); MINN. STAT. ANN. \$ 611.21(b) (West Supp. 1994) (\$1000 limit on compensation paid for expert defense services); NEV. REV. STAT. ANN. § 7.135 (Michie 1986 \& Supp. 1993) (reimbursement for expenses for expert services is not to exceed $\$ 300$ unless authorized by the court); N.H. REV. STAT. ANN. \& 604-A: 6 (Supp. 1993) (the court may authorize counsel to obtain necessary services exceeding $\$ 300$ ); N.Y. COUNTY LAW $\$ 722$ (c) (McKinney 1991 \& Supp. 1994) (court may authorize counsel to obtain necessary services, not to exceed $\$ 300$ unless extraordinary); TEX. CODE CRIM. PROC. ANN. art. 26.05(a) (Vernon 1989 \& Supp. 1994) (a reasonable fee may be set by the court for investigation and expert testimony); see also HAW. REV. STAT. \$ 802-7 (Michie 1994) (funding for expert defense services is to be paid from available court funds); N.C. GEN. STAT. \$ 7A-454 (Michie 1989 \& Supp. 1994) (at court's discretion, approval may be given for fees for the service of expert witnesses); OR. REV. STAT. ANN. $\$ 135.055$ (3) (1990) (reasonable expenses for expert defense services, in the discretion of the court, may be authorized); TENN. CODE ANN. \$ 40-14-207(b) (1990 \& Supp. 1993) (where expert defense services are determined to be necessary in a capital case, court can authorize appropriate services).

352. See, e.g., AlASKa STAT. $\$ 12.47 .070$ (Michie 1990 \& Supp. 1993) (upon notice of a defendant's intent to use the insanity defense, the court will appoint two qualified psychiatrists); ARIZ. REV. STAT. ANN. § 13-4013(B) (1989 \& Supp. 1993) (psychiatric experts are court appointed, and available for capital cases only) (extended to noncapital cases in State v. Peeler, 126 Ariz. 254, 614 P.2d 335 (Ariz. 
and legal aid programs. ${ }^{353}$ These services are legislatively imposed and are, therefore, more consistently enforced than in states where the trial courts act at their own discretion. ${ }^{354}$

Perhaps a way around caps placed on expert and investigative services is for a state court to declare that the caps are not absolute allowances, but rather are limitations on state funds allocated for the defense of indigents. Counties would then be required to supplement state funds as required to ensure competent representation in any given case. The determination of the amount of county funds to be required in a given case would rest in the sound discretion of the trial court. This was the approach taken recently by the South Carolina Supreme Court in Bailey v. State. ${ }^{355}$ In Bailey, the court held that the South Carolina statute providing for caps of $\$ 5000$ for attorney's fees and $\$ 2500$ for experts and investigative services in capital cases were only state caps and that counties throughout the state would have to supplement these fee and expert service caps as necessary in a given case. ${ }^{356}$ As to the trial court's discretion, the Bailey court indicated that the court should approve such reasonable expenses as would be plainly necessary for the defendant to have his day in court and to permit counsel to fairly and adequately present his case. ${ }^{357}$

1980)); see also FLA. R. CRIM. P. 3.216(a) (West 1989 \& Supp. 1994) (upon notice of intent to use the insanity defense, the court must appoint defense experts); IND. STAT. ANN. § 35-36-2-2 (Burns 1994 \& Supp. 1994) (upon notice of a defendant's intent to use the insanity defense, the court will appoint two or three "competent disinterested" psychiatrists or clinical psychologists to examine the defendant and testify at trial); MONT. CODE ANN. \& 46-14-202(1) (1993) (upon notice of the defendant's intent to use the insanity defense, the court will appoint at least one qualified psychiatrist or licensed clinical psychologist to examine the defendant); OHIO REV. CODE ANN. § 2945.39 (Banks-Baldwin 1992 Supp. 1993) (examiners are appointed by the court, but the defendant may recommend a preferred examiner if more than one examination is ordered).

353. DEL. CODE ANN. $29 \S \S 4601-4608$. (1991 \& Supp. 1994) (creating a public defender's office); N.J. STAT. ANN. §\$ 2A:158A-1-:158A-25 (West 1985 \& Supp. 1994) (creating a public defender's office); W. VA. CODE $\S 29-21-13 a$ (c) (Michie 1992 \& Supp. 1994) (providing for reimbursement of up to $\$ 1500$ for expenses incurred by public defenders or panel attorneys for expert witnesses); WIS. STAT. ANN. $\S \S 977.01-10$ (West 1985 \& Supp. 1994) (creating a public defender's office).

354. See, e.g., State v. Olin, 648 P.2d 203 (Idaho 1982) (acknowledging that a defendant's request for expert services should be measured against due process standards, the court nonetheless held that whether or not a particular defendant is entitled to expert defense assistance at state expense is in the discretion of the trial court); State v. Anaya, 456 A.2d 1255 (Me. 1983) (retreating from earlier standard which provided an indigent defendant with expert defense assistance whenever a reasonable attorney would engage an expert, and adopting a requirement that the indigent defendant demonstrate to the trial court that his need for psychiatric defense assistance is essential or necessary to an adequate defense); Collins v. State, 288 A.2d 221, 224 (Md.), cert. denied, 409 U.S. 882 (1972) ("[T] he majority of jurisdictions, including Maryland, have held that the supplying of expert pretrial services to indigent defendants in criminal cases at public expense is a matter within the sound discretion of the trial court.").

355. 424 S.E.2d 503 (S.C. 1992).

356. The court noted that the per-hour rate of $\$ 15$ for in-court time and $\$ 10$ for out-of-court time were the lowest in the nation. Id. at 508 n.4.

357. Id. at 509 (citing Arnold v. Kemp, 813 S.W.2d 770, 777 (Ark. 1991)). In Amold, the Supreme Court of Arkansas struck down the state statutory expense and fee cap as being unconstitutional on both equal protection grounds (Arkansas is a "mixed" state where some counties have public defenders and some counties proceed with private or panel attorneys for the representation of indigent defendants) and the fact that statutory expenses and fee caps imposed on court-appointed attorneys for individual clients accused of crimes was excessive and constituted a "taking" of property in violation 


\title{
A. Suggested Statutory Language for Authorization of Defense Services
}

The cases discussed in Parts III, IV, and V of this article generally suggest a number of after-the-fact tests to aid appellate courts in deciding whether a defendant is entitled to a new trial based on a trial court's denial of an expert. Such tests include whether the requested expert's testimony would have been admissible on a pivotal issue so as to bear on the defendant's innocence; whether other independent evidence supports the defendant's guilt (a "harmless error" test); whether any expert offered testimony on the issue; whether the lawyer could have performed the work he sought an expert to do; whether the lawyer exhibited competence in dealing with a government expert; and whether the request made by counsel for the defendant was timely.

It is apparent that much more guidance is needed at the trial court level, where the judge must decide in the first instance whether an expert for a defendant should be allowed. There simply is not enough protection in the due process/fundamental fairness/right to assistance of counsel standards.

Reviewing the record to determine whether fundamental fairness was accorded to an indigent defendant after the trial has been completed ignores the purpose of section $3006 \mathrm{~A}(\mathrm{e})$ of the CJA and comparable state statutes, which is to provide the defendant and his counsel with knowledge to use at trial. As the Second Circuit has stated:

\begin{abstract}
We have given serious consideration to merely remanding for appointment of an expert whose report could then be considered by the trial court or by us in deciding whether to grant a new trial. But we believe this misconceives the purpose of providing expert service to the defense. It is not to supply either the trial or appellate court with anything, but to furnish defense counsel expert information to use as he sees fit. ${ }^{358}$
\end{abstract}

Moreover, it is virtually impossible to decide before trial whether denial of an expert will deny a defendant fundamental fairness. ${ }^{359}$

Thus, where a reasonably competent attorney in good faith requests defense services, such request should be granted. A trial judge need not act in a vacuum; the court can require a motion and affidavit showing need. However, where defense counsel can articulate specific and affirmative facts on which he bases the belief that a certain expert is warranted or would be helpful to the defense, the motion should be granted. This is basically the standard

of the 14th Amendment. 813 S.W.2d at 772-76; see also DeLisio v. Alaska Superior Court, 740 P.2d 437 (Alaska 1987); Makemson v. Martin County, 491 So. 2d 1109 (Fla. 1986); State ex rel. Stephan v. Smith, 747 P.2d 816 (Kan. 1986).

358. United States v. Durant, 545 F.2d 823, 829 (2d Cir. 1976).

359. Id. 
formulated by Judge Wisdom in United States $v$. Theriault. ${ }^{360}$ Judge Wisdom's standard has been embraced by both federal and state courts. ${ }^{361}$ If this standard were uniformly adopted, it would eliminate the showing of "necessity" and shift the burden of making the decision from the court to defense counsel. Proposed federal and state statutory wording could be as follows:

A defendant who has been qualified to proceed as an indigent in a criminal case and who is unable to obtain investigative, expert, or other services for his defense may request them in an ex parte application to the court filed by defense counsel. The court shall authorize defense counsel to obtain services on behalf of the defendant when:

(A) (1) there is a timely request by defense counsel, accompanied by a motion and affidavit setting forth specific facts and reasons why the request is necessary or helpful to an adequate defense; or (2) whenever the government has indicated by pretrial discovery or at a pretrial conference that it will be offering the testimony of an expert, and the defense deems it appropriate to retain a defense expert to testify as to the same facts or legal issue; and

(B) the court makes a finding that the defendant is financially unable to obtain the requested defense services; and

(C) defense counsel certifies that the case is one that will result, or is likely to result, in a contested trial. ${ }^{362}$

If this proposed statutory language were enacted, defense counsel would be forced to allege specific facts to support the belief that a defense expert is necessary. Trial courts then would have considerably more information on which to make an informed ruling, and appellate courts would have a more complete and better record to review for abuse of discretion. This does not mean that frivolous motions should be entertained seriously, but only that a trial court should give meaning to the right of an indigent defendant to the effective assistance of counsel. That is, effective counsel will do what is necessary to represent his client properly by filing a detailed and fact-specific motion for defense services, and the trial court will honor good faith representations made by defense counsel. ${ }^{363}$

360. 440 F.2d 713, 716-17 (5th Cir. 1971) (Wisdom, J., concurring). In Theriault, Judge Wisdom read the legislative history and policy basis of section $3006 \mathrm{~A}(\mathrm{e})$ to compel the conclusion that "authorization for defense services [is required] when the attorney makes a reasonable request in circumstances in which he would independently engage such services if his client had the financial means to support his defenses." Id. at 717.

361. See, e.g., United States v. Alden, 767 F.2d 314, 318 (7th Cir. 1984); United States v. Sims, 617 F.2d 1371, 1375 (9th Cir. 1980); Brinkley v. United States, 498 F.2d 505, 509.510 (8th Cir. 1974); United States v. Chavis, 486 F.2d 1290, 1291 (D.C. Cir. 1973); State v. Coker, 412 N.W.2d 589, 592 (Iowa 1987); State ex reL Foster v. Luff, 264 S.E.2d 477, 479 (W. Va. 1980).

362. A statutory proposal somewhat similar to the one recommended in this article was made in 1982 in an article on expert services. See John F. Decker, Expert Services in the Defense of Criminal Cases: The Constitutional and Statutory Rights of Indigents, 51 U. CIN. L. REV. 574, 614-15 (1982).

363. Statutory provisions should also be made to provide government- or state-funded experts for use at sentencing, as opposed to trials. This would enable defendants to develop mitigating facts at sentencing, an especially acute need in death penalty cases. 
Indigent defendants will be able to compete with the prosecution in cases where fact investigation and/or expert witnesses will decide the outcome of trial only by a shift away from after-the-fact tests to determine whether a defendant was prejudiced by a denial of expert services and toward more progressive legislation in the area of granting defense services, and by more state supreme court holdings striking down fee and expense caps as unconstitutional. In short, the "tools of an adequate defense" 364 lose validity when they are inaccessible to defense attorneys.

\section{B. Interpreting the "Significant Factor at Trial" Test in Terms of Reasonableness}

Based on a review of lower court decisions since $A k e$, it is clear that $A k e$ 's promise of attaining "[m]eaningful access to justice"365 for indigent defendants has not been fully realized. This lack of attainment looms large, in light of the frequency with which the issue of the right to expert services for indigent defendants arises in capital cases and the increasing importance of expert assistance in all criminal cases. ${ }^{366}$ The question, then, remains: How should lower courts implement $A k e$ ?

If one views the issue in the larger context of what the Supreme Court attempted to accomplish in Ake, the standard articulated in Moore v. Kemp ${ }^{367}$ and other variants of the Moore test seem overly strict. While the right announced in Ake was based on the due process clause, the opinion itself contains much language in the area of equalizing justice between the rich and poor. ${ }^{368}$ Thus, the Moore standard has the exact opposite effect.

A reasonableness standard, similar to that adopted in Sommers v. Commonwealth ${ }^{369}$ would fully satisfy the policy objectives of Ake. In Sommers the court had to interpret the word "necessary" in a state statute providing for expert services to an indigent accused of a crime. The court held that a defendant's request for the use of an expert witness in preparation of his defense must be measured by a standard of reasonableness and should be allowed when the facts show that use of the expert would be "reasonably necessary" to the accused in preparing his case. ${ }^{370}$ Unlike Moore, Sommers

364. Britt v. North Carolina, 404 U.S. 226, 227 (1971).

365. Ake v. Oklahoma, 470 U.S. 68,77 (1985).

366. ANDRE A. MoENSSENS et AL., SCIENTIFIC EVIDENCE In CRIMINAl CASEs iii (3d ed. 1986) (noting that scientific evidence and expert testimony are increasingly vital in criminal investigations and trials as a consequence of increasing specialization of knowledge and problem solving).

367. 809 F.2d 702 (11th Cir.), cert. denied, 481 U.S. 1054 (1987); see supra note 137.

368. See, e.g., Ake, 470 U.S. at 76-77.

369. 843 S.W.2d 879, 882-85 (Ky. 1992).

370. Id. at 883; accord Vassar v. Solem, 763 F.2d 975, 977 (8th Cir. 1985). Commentators have suggested similar standards. See Harris, supra note 91, at 781 (stating that a "reasonableness standard, akin to that adopted in Vassar ... would fulfill the underlying policy objectives of $A k{ }^{\prime \prime}$ ); William D. Auman, Note, Criminal Procedure-Defendant's Due Process Right to a Psychiatric Expert-Ake v. Oklahoma, 8 CAMPBELL L. REV. 323, 334 (1986) (Because insanity is a potentially dispositive defense, "the requirement of a preliminary showing in $A k e$ should be construed in a flexible manner to recognize 
does not require that the defendant prove prejudice or lack of a fair trial without the use of the expert. Moreover, the reasonableness standard is consistent with the rationale of $A k e$ that a court should presume a trial would be unfair if the defendant does not receive expert assistance when the defendant's sanity is a significant factor. Whereas Moore, which requires that a defendant prove the trial will be fundamentally unfair, is not consistent with the Ake rationale.

In contrast to the rigid requirements of Moore, construing Ake in terms of reasonableness would give lower courts flexibility to respond to the facts. Under the Sommers reasonableness standard, a lower court would view $A k e$ by allowing defendants to receive help in those cases in which a defense expert's testimony (or aid in preparing a cross-examination) relates to a reasonably significant factor at trial, even if this would result in some defendants with marginally justified expert requests receiving assistance. The reasonableness standard would also recognize that the motion for expert assistance must be made before trial, during early stages of investigation and factual development.

\section{VII \\ CONCLUSION}

More than sixty years ago, the Supreme Court determined that the assistance of counsel was constitutionally mandated. ${ }^{371}$ Almost forty years ago, a free transcript was deemed necessary to preserve an indigent's constitutional rights. ${ }^{372}$ Ten years ago, with $A k e$ in 1985, expert psychiatric assistance was recognized as a necessary incident to a fair trial. ${ }^{373}$ Since $A k e$, a number of state courts have struck down fee and expert services caps either as not being absolute maximums or as being unconstitutional. ${ }^{374}$ This progression represents a continuing redefinition of the adequate tools that must be furnished to an indigent defendant in order to meet constitutional standards.

Experts, both psychiatric and nonpsychiatric, are an integral part of today's complex trials at both the federal and state level. Ake suggested that when the issue to be addressed by an expert would be a significant issue at trial or necessary to an adequate defense, the expert presumptively was necessary. Ake dealt solely with the indigent's right to a psychiatric expert. However, an analysis of $A k e$ and its constitutional underpinnings suggests that the $A k e$ mandate logically should extend to the nonpsychiatric expert as well. Unfortu-

and reflect the public concern of a fair and accurate resolution of issues."); Craig Bowman, Note, The Indigent's Right to an Adequate Defense: Expert and Investigational Assistance in Criminal Proceedings, 55 CORNELl L. REV. 632, 644 (1970) ("The most reasonable formula is to provide ... services . . a at public expense to the extent that a refusal of funds in a particular case will work undue hardship on the defendant.").

371. Powell v. Alabama, 287 U.S. 45 (1932).

372. Griffin v. Illinois, 351 U.S. 12 (1956).

373. Ake v. Oklahoma, 470 U.S. 68 (1985).

374. See supra notes $355-57$ and accompanying text. 
nately, most post-Ake lower federal and state courts have been miserly when evaluating nonpsychiatric expert requests made by indigent defendants. ${ }^{375}$

New legislation liberalizing the standards for ruling on such defense motions is needed, as is a broader interpretation of Ake by the courts. Given the sophisticated, complex trials of today, an indigent defendant denied expert assistance cannot be said to have an adequate defense. More than sixty years ago, then Chief Justice Cardozo of the Court of Appeals of New York penned words that have even greater meaning today: "[U]pon the trial of certain issues ... experts are often necessary both for prosecution and for defense .... [A] defendant may be at an unfair disadvantage, if he is unable because of poverty to parry by his own witnesses the thrusts of those against him." ${ }^{376}$ The indigent defendant must be provided the necessary tools with which to defend adequately against the power of the prosecution; otherwise the $A k e$ mandate is meaningless. In the absence of a more fixed duty on trial courts to provide independent experts for the indigent, it is likely that the type of trial an accused will receive will sadly depend on the depth of his or her pocket.

375. Since Ake was handed down, only two courts have found the denial of a nonpsychiatric expert to be a denial of due process. In Little v. Armontrout, the Eighth Circuit held that the defendant's fourteenth amendment right to due process was violated when the trial court refused to appoint a hypnotist for him. 835 F.2d 1240, 1242-45 (1987) (en banc), cert. denied, 487 U.S. 1210 (1988). In State v. Coker, the Supreme Court of lowa held that the trial court abused its discretion in not granting a motion for an expert to assist Coker in the preparation of an intoxication defense. 412 N.W.2d 589 (1987). Other courts have, however, reversed convictions and granted a new trial where experts were denied at the trial court level based on the trial court's erroneous interpretation of state law. See Caldwell v. Mississippi, 472 U.S. 320 (1985); see also Sommers v. Commonwealth, 843 S.W.2d 879 (Ky. 1992).

376. Reilly v. Berry, 166 N.E. 165,167 (N.Y. 1929). 